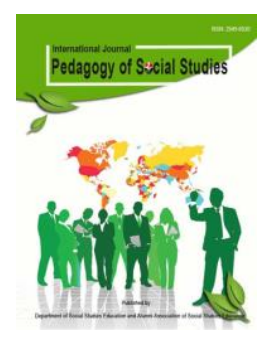

\title{
Community Development Education: \\ Examining Students' Video-Based Case Analysis on Community Issues, Indigenous Ethnic Protection and Empowerment
}

\author{
Adi Suryani $^{1}$, Soedarso ${ }^{2}$, Wahyuddin ${ }^{3}$, Moh Saifulloh ${ }^{4}$, Siti Zahrok ${ }^{5}$ \\ Departement of Development Study, Faculty of Creative Design and Digital Business \\ Institut Teknologi Sepuluh Nopember, Surabaya, Indonesia
}

\begin{abstract}
One of many development efforts is increasing today students development issues care and awareness. They are going to be the future nation developers and leaders. Thus, it is significant to promote understanding on various community development issues and stimulate their analytical thinking and problem solving. Video is one of many educational means to assist students' learning process. It provides authentic materials and feeling experience of being there, instead of bringing the students to the real hazardous jungle. This study aims to analyze student-participants analysis on Dayak indigenous community issues and problem solving stimulation using a case study video. Qualitative research method is employed to achieve the research objectives. Thirty-five students are participating in the study. The studentparticipants written responses are analyzed by classifying them into emerging themes and categories, interpreting the underlying meaning and linking to the findings of existing projects, researches, and projects on development. The study reveals that the student-participants propose four main solutions. Those are environment and culture care, external development agents inclusion, capacity building and adaptive capacity development.
\end{abstract}

Keywords - community development, case-study video, indigenous community

Correspondence. soedarsoits@gmail.com

Article History. Received January 2020, Received in revised April 2020, Accepted June 2020

C2020. International Journal Pedagogy of Social Studies. Department of Social Studies

\section{A. INTRODUCTION}

The prevalence of information, communication and technology changes the nature of learning and teaching. Traditionally, teaching practices are restricted to printed text, direct face to face interaction and enabled by conventional learning/education systems and mechanisms. Nowadays, many technological tools disrupt this existing educational construct. The advancement of technology provides more flexible learning environment, accommodates more diverse learning styles, stimulates higher thinking order, promotes more (authentic) learning experiences, presents wider range of learning materials, encourages emotional, cognitive and motoric engagement. Currently, these benefits are heightened by the easier access of internet allowing rapid and broad flow of information, increasing disseminated result on teaching with technology and internet produced by existing researches and teaching practices and stronger motivation of teachers and learners to study things differently (as opposed to the conventional approach).

One of many technological-based educational tools is video. The popularity and benefits of video usage in education is undoubtedly. Video can easily attract learners' attention and emotion since it presents materials visually and auditorily. Video brings authentic context for learning and it allows learners to feel 'being there' without 'actually being there.' For instance 
educational video on space gives learners experiences of space journal, video on deep underwater offers unreachable undersea insights. Watching video can make the viewers feel like being there (Troseth, 2010, cited in Troseth \& Strouse, 2017, p. 4). The use of video in education also allows repeated simulated learning as video enables learners to focus on certain course of simulated materials as learners can re-play and pause. The advancement of media social intensifies the benefits of educational video. YouTube becomes significant learning resources from which teachers and learners can explore their learning materials by needs and interests. The prevalence of whatsapp today accelerates learning process by allowing rapid, simple and handy transmission of video.

This study aims to explore educational function of video to support students' analysis and problem solving on development issues. The authors find that videos are popular simulated tools at health and medicine disciplines (Aljamal et al., 2020; Green et al., 2019; Hurtubise et al., 2013; Lehmann et al., 2016; Mota et al., 2018; Schmitz et al., 2020), economic, marketing and business (Kuhn et al., 2018; Lehmann et al., 2016; Orús et al., 2016) and other disciplines, including agriculture, nutrition, engineering. However, the use of video for promoting development purposes, especially indigenous people protection and empowerment remains unexplored. Thus, this study aims to add knowledge gap in educational video utilization by addressing role of video as development analysis tool in a certain development case. It is concentrated on how video can function of stimulant for a development issue problem solving.

\section{B. LITERATURE REVIEW Video as Learning Tools}

Many existing researches and studies address the educational benefits of using video in classrooms. Video is increasingly utilized as educational tool (Biard et al., 2018; Brame, 2016; Eady \& Lockyer, 2013; Yip et al., 2019) as today's learners need different teaching methods and new literate forms compared to their predecessors (Bello-Bravo \& Baoua, 2012; Greenberg \& Zanetis, 2012; Liimatta, 2015; Oliveira, 2018, p. 298; Rajadell \& Garriga-Garzón, 2017). Video as learning tool is used by various fields of studies, including economics (Kuhn et al., 2018), nutrition (Ramsay et al., 2012), education, medicine agriculture (Spolaôr et al., 2020), marketing (Lehmann et al., 2016; Orús et al., 2016), surgery (Green et al., 2019; Mota et al., 2018), neuroscience (Papathomas \& Goldschmidt, 2017), English language (Masats et al., 2009; Nova et al., 2017), mechanical engineering (López et al., 2016), medical education (Hurtubise et al., 2013), mental health (Stiberg et al., 2012), language learning (Chan, 2014). The use of video in higher education challenges the traditional lecture methods (Brame, 2016; Woolfitt, 2015)

Video brings about positive impacts on learners' cognition, affection and psychomotor. Video advances information and cognition content (Biard et al., 2018), activates learners' meta-cognition awareness (Alt1ok et al., 2019), increases cognitive knowledge (Cruse, 2006; Habes et al., 2020). Video is a tool for learning how to extract cognitive value (Shoufan, 2019), promotes critical thinking in problem-based learning (Roy \& McMahon, 2012), triggers innovation and creativity in presenting information (Ramsay et al., 2012), transfers knowledge and constructs schema (Liao et al., 2019), adds content interactivity, engagement and knowledge development (Greenberg \& Zanetis, 2012).

Video can attract learners' attention, increase their motivation and emotion engagement. Video makes the materials presented are more attractive (Yousef et al., 2014), stimulate students' cognitive, emotion engagement (Carmichael et al., n.d.) and interaction with learning materials (Carmichael et al., n.d.), learning emotion and motivation (Bravo et al., 2011; Cruse, 2006; Ljubojevic et al., 2014; Ramsay et al., 2012). Video is a tool for entertainment (Yip et al., 2019, p. 89). Besides affective 
learning tool, video is an equipment for increasing psychomotor skills (Wang et al., 2020). Social competences (Greenberg \& Zanetis, 2012; Reining et al., 2019) and values of care and relationship can be facilitated by the use of video (Stiberg et al., 2012). Video is easy to use, interesting and opening learners' mind before main material (Fahrurozi et al., 2017).

Video is an adaptable educational tool, which can be adapted to different learning purposes. Thus, it can promote development of learners' various skills. It offers benefits for facilitating a wide range of certain skills, for instance clinical and leadership skill teaching which is facilitated by guided video reflection (Wang et al., 2020), teachers' feedback skills by deploying digital-video feedback environment (Prilop et al., 2020), surgical skills enabled by group video (Aljamal et al., 2020) or 3D HD video system (Kotsougiani et al., 2016), cooking skill (Surgenor et al., 2017), eco driving training tool by using instructional video and interactive guidance (Beloufa et al., 2019), video-based worked examples for breaking bad news in simulated patients (Schmitz et al., 2020), pediatric physical examination skill facilitated by video-based blended learning (Lehmann et al., 2016), clinical skills (Forbes et al., 2016), surgical education (Green et al., 2019), surgical education (Mota et al., 2018), geriatric (Habes et al., 2020), teacher professional development/teaching skills (Bryan \& Recesso, 2006; Chen, 2020; Santagata \& Stürmer, 2014; Tripp \& Rich, 2012), English language skill (Nova et al., 2017), critical thinking, problem solving, and decision-making (Thieman, 2008), presentation skill (Guo, n.d.).

The use of video offers pedagogical options and variety. Video is a part of instructional strategy (Forbes et al., 2016) and helping tool for teachers in designing materials to enable students understand materials better (Layona et al., 2017) and improving teaching pedagogy (Oliveira, 2018) for learners' satisfaction and results (Orús et al., 2016). It accommodates various learning styles (Cruse, 2006). Thus, it can be used for catering any learning types: individual, collaborative, distance or direct learning. Video allows autonomous/selfregulated information processing (Merkt et al., 2011) and joint-activities (Liao et al., 2019) through collaborative learning (Mavrou et al., 2007), such as in forms of learning communities, learning clubs (van Es, 2012), video clubs (Charalambous et al., 2018).

Video is a flexible learning tool. It can be combined by other learning methods to maximize learning potentials. There are several aspects which teachers consider in using using educational video: fitting video with learning goals, emphasizing key learning concepts and embedding video into other types of pedagogy/learning modes (Brame, 2016). Many studies examine the potential incorporation of video with other pedagogies in blended learning. Video encourages the prevalence of blendedlearning approach (Coyne, et al., 2018). Blended learning approach allows the joint activity of face to face interaction and technological mediated teaching can result in improved students' learning outcomes (Liu, 2016). The integration of video in blended learning to provide authentic situation is getting more popular in education (Coyne, et al., 2018). Blended learning assisted by video offers benefits of flexibility (Coyne, et al., 2018), increases of learners' understanding on best practices and theory-practice connections (Coyne, et al., 2018). Certain type of explanation can be best demonstrated using video, for instance the simulation learning type (Coyne, et al., 2018; Dudas \& Wheeler, 2020; Ohlenburg et al., 2017) as it provides clear practical demonstration (Carmichael et al., n.d.).

The elaboration of video into other teaching methods shows that video cannot be used as single or mono learning tool. As mentioned by Brame (2016), to use video in learning, several aspects need to be considered, including how to manage cognitive content, students' engagement and active learning can be facilitated. Watching video only can lead to passive activity. Thus, it should be blended with active learning method. Viewing video is not passive activity, if it is well embedded in and incorporately designed with high cognitive 
learning activity (Mayer, 2001, p. 19, cited in Cruse, 2006, p. 3). Active learning is indicated by teachers' and students' engagement to understand learning content through discussion, problem solving, critical thinking or debate (Promoting Active Learning, n.d., cited in Acharya et al., 2017, p. 71). Effective educational videos usage is indicated by several features: active learning, cognitive load and emotion engagement (Ellis \& Childs, 1999).

Currently, the prevalence of internet strengthens the benefit of educational video. Today's learning environment is enriched by YouTube as teaching resource (Burke et al., 2017) and social media, such as "Pinterest, Facebook, Twitter, YouTube, LinkedIn, Second Life, and Skype (Delello et al., 2015). Social media as supplementary learning media can work together with video (Liu, 2010; Moghavvemi et al., 2018). Internet, incorporates with video, enables distance and remote learning (NSW Department of Education, n.d.). Video embedded in multimedia increases students' learning experience (Ljubojevic et al., 2014). The advancement of other electronic and technological devices also complements the role and use of video in education. Mobile phone cameras, for instance, become prevalent educational tool (Bello-Bravo \& Baoua, 2012; Gilbert \& Bowden, 2017). They are used for different educational goals, including increasing students' reading, writing and speaking learning outcomes (Gromik, 2012), observing and learning natural phenomenon, such as volcano (Witsil \& Johnson, n.d.). Embedded video in Whatsapp application can facilitate learning (Gon \& Rawekar, 2017). Specific type of video is used and designed to address specific learning goals, such as augmented reality video can be better to be used for delivering complex task/concept, for instance threading (Yip et al., 2019, p. 100), resulted in increasing students' learning satisfaction and experience compared to handout materials (Yip et al., 2019). Virtual reality technology (360-degree video) (Rupp et al., 2019) and question-embedded interactive video environment (QVE) (Vural, 2013), increase learners' learning experiences (Rupp et al., 2019). Instructional video with instructors' presence increases learners' attention, mental attempt, engagement and selfregulation (J. Wang \& Antonenko, 2017, p. $88)$.

\section{Problem Based Learning}

Problem-based learning is one of active learning method which is adopted by many disciplines. Problem-based learning is used inter-disciplinary and across various fields, including physics (Argaw et al., 2017), business (Hartman et al., n.d.), vocational studies (Kusumatuty et al., 2018), mathematics, science and technology (Gorghiu et al., 2015), project-based science (Chin \& Chia, 2008) and multi-discipline (Savery, 2006).

Problem-based learning is one of active learning pedagogy which presents inconsiderable educational benefits, especially for facilitating problem solving skills. Problem-based learning aims to develop students' flexible insights, problem solving skills, self-directed learning skills, collaborative and motivation (Hmelo-Silver, 2004). Problem based learning develops students' learners' problem solving skills (Argaw et al., 2017; Hartman et al., n.d.), allows the students to identify problems (Hartman et al., n.d.), problem elicitation, working together for proposing problem solving (Gorghiu et al., 2015). Problembased learning empowers students to examine, link theory to practice, implement knowledge and skills and propose solution for certain problems (Savery, 2006). The learners are encouraged to work for solving authentic issues in problem-based learning (Marra et al., 2014). Thus, it increases learners' cognitive skills (Hartman et al., n.d.).

Besides impacting on cognition, problem-based learning influences learners' other learning skills, including affection, life-long learning and team capacities. Problem-based learning promotes learners' meta-cognition (Marra et al., 2014), 
independent-learning skills (Eng, n.d.), students' capacity for learning how to learn (Gorghiu et al., 2015), collaboration learning experiences (Christiansen et al., 2013), learners' responsibility for their own learning process (Hmelo-Silver \& Barrows, 2006), team cohesion (Hartman et al., n.d.), leadership skills (Scott, 2017), allows learners to retain their knowledge longer (Yew \& Goh, 2016). Problem-based learning produces long-term impact for learning. The capacity for solving problem will be used in any situation in real life context (Gorghiu et al., 2015).

Problem-based learning is implemented through several learning cycles. Problembased learning is started with defining problems, making questions, defining students' knowledge and needs, structuring ideas, developing students' aims, conducting out-of-class-research, analyzing new information (Kosel et al., 2005). Problembased learning is performed through a sequence of problems, facts, questions, plan, research, report, solution, reflection (University of Rochester, 2009). Similarly, De Graaff and Kolmos (2003) list several steps in problem-based learning: identifying specific real-life based problems, investigating, arriving at decision making and reporting, engaging in inter-disciplinary, exemplary and team-based learning (De Graaff \& Kolmos, 2003). Learners-centred, self-directed, self-reflective and facilitative learning are the centres of problem-based learning (Marra et al., 2014). Problem-based learning is characterized with pupil centred, flexible learning environment, relevant learning, active and experiential learning, logical, collaborative, efficient, authentic and integrative (Gorghiu et al., 2015). Problembased learning emphasizes student-centred, constructing process, flexible situation and relevant to specific context (Sir Wilfrid Laurier School Board, n.d.). In implementing problem-based learning, teachers fulfill diverse roles, including coaching, guiding students to examine and solve the problems and advancing their cognitive capacity (Gorghiu et al., 2015), designers and practicing (Christiansen et al., 2013), presenting problems, guiding, co-learning and assessing (University of Rochester, 2009), facilitating (Hmelo-Silver, 2004; Hung et al., 2008) and supporting collaborative knowledge construction (Hmelo-Silver \& Barrows, 2006).

\section{Understanding, Community Issues, Indigeneous Ethnic Protection Empowerment}

Identifying, solving and developing community remain the big challenges in development studies. Many community issues, such as poverty, prosperity, equity, housing (Community Investment, 2012) call attention many development agents to figure out ways and approaches to tackle the problems by defining, understanding and proposing strategies of community development. Many development efforts, projects and programs are devoted to tackle interlocking community issues, including education, women empowerment, child mortality, environmental sustainability (Excellence in Social Responsibility. Community Development, n.d.), local community mindset, lack of information, cultural heritage, job vacancies and road facilities (Putra \& Rudito, 2015), gender and inclusion, indigenous people and human rights (ICMM, n.d.). It is executed to address complex issue, such as poverty which is resulted from interlocking systemic inequalities (Bamber et al., 2010), discrimination, disadvantages and social exclusion (SCDC, n.d.). Several studies explore some main goals of community development programs. Excellence in Social Responsibility. Community Development (n.d.) asserts that community development is executed for building prosperous and healthy, equitable, initiative, selfsufficiency, individual worth, dignity, valued and conscious community. Community development program tends to be focused on different community aspects of economic, environment, physical-natural, social, civic, people and human resource (Taylor, n.d.). Thus, community development programs are usually intended to target specific community member or goal, such as development programs for child, women, youth, senior citizens, family and health, agriculture, public services, 
education and communication (Sureshkumar et al., 2015). Secure, healthy, prosperous, well-governed economical, predictable financial situation are several community condition aimed to be achieved from community development projects (Excellence in Social Responsibility. Community Development, n.d.). Community development addresses several aspects: fulfill community needs fulfillment, actions mobilization, individual and community capacity development, participation increase and quality of life enhancement (SDCS et al., n.d.).

To run successful community development program, local community engagement is required. Community development needs community participation, shared action, democracy, empowerment, problem based learning, collaboration and preventive measures (SCDC, n.d.). Community inclusion is key determinant of community engagement. This can be done by listening to the community needs and desires, activating community contribution, enabling self-help and adopting community holistic view (Community Development, n.d.), strengthening community sense of belonging (Riach, 2002). Community development encourages social inclusion (SCDC, n.d.). The need of social inclusion is also confirmed by Riach (2002) who emphasizes that local community involvement, local knowledge and talents respect, sustainability, local capacity development and effective communication determine the outcomes of community development. Community development also relies on local community collective learning capacity. Community vitality can be promoted by building a learning community, a community who is capable of analyzing their own assets, developing partnerships, networks, possessing internal interests and motivation to progress (Cavaye, 2001). A healthy community development programs are based on principles of social justice, self-reliance, equality, learning and cooperation (Central Land Council, 2012), rights, participation, democracy, empowerment and alleviation of racism, class and state (Bamber et al., 2010). Injustice can be alleviated by promoting social justice, democracy, human right, equal chances collectively and collaboratively (Bamber et al., 2010, p. 23). The implementation of community development can be impeded by several challenges. As revealed by (SDCS et al., n.d.), the main challenge of community development is residing administrative structure political power, institutions and influence of other communities and power relationship with power at formal government. This is because community development is also affected by establishing policy (Chiarenza, 2013). Similarly, Cavaye (2001) finds that mobilizing participation, managing perceptions, promoting community self-efficacy and changing government role are big challenges in community development. Furthermore, ICMM (n.d.) identifies tools for running community development program covering planning, monitoring, assessment, management and relationship.

Indigenous community is susceptible to community development issues. They are vulnerable to natural resources exploitation, territories exploitation, human resource exploitation for other community development, commercial studies/projects, relocation, colonization and protected areas creation (Beltrán, 2000), racial discrimination (Hooker, 2005), illegal hunting (Nepal, 2002), conflict between external agencies and indigenous people (Nepal, 2002), social inequality (Mendoza, 2016). Indigenous community development means the inclusion of local initiatives, knowledge and intention and implementation of development project by considering local economic, social and natural environment (Sureshkumar et al., 2015). Successful indigenous community is determined by local community inclusion. Cooperation with indigenous people will empower indigenous people (Mendoza, 2016) as inclusion decreases inequality (Mendoza, 2016), while Nepal (2002) suggests consultation and indigenous people 
involvement in development program to empower them. Community empowerment for indigenous community can be done by restoring biodiversity loss and restoring them (Hill et al., 2011). Indigenous people life can be protected by developing understanding long relationship between indigenous people and nature/protected areas, respecting indigenous people right, land and territories, involving them, equally sharing benefits of development and understanding shared responsibilities (Beltrán, 2000).

\section{METHOD}

The study aims to analyze and present students' analysis on indigenous community issues and students' capacity to propose several problem solving. A video is used to present authentic material by displaying the real situation and issues of an indigenous community. The video is used as thinking stimulant and a tool for emerging students' diversities and complexities of authentic analysis and problem solving. To achieve those aims, a qualitative method is employed. A qualitative method is used to capture participants' authenticity in understanding people understanding through open-ended questions (Silverman, 2010, p. 20).

The participants of the study are thirtyfive students. The data are gathered from a classroom activity and students' assignment. The classroom activity is proceed by integrating technology (a case study video) and community development content. During the activity, the student-participants are played a video, entitled Dayak Challenge in the $21^{\text {st }}$ Century-Cultural Displacement. After listening, the students are asked to develop an issue analysis and problem solving essay. An open-ended question on a case study is given to the student-participants to encourage their critical analysis and problem solving. Case study is frequently associated with qualitative data and analysis (Rutterford, 2012, p. 119). A case study is a method used to gather systematical information on certain people, social context, event, group and allows the researchers to understand how they are operating or functioning (Berg, 2000, cited in Rutterford, 2012, p. 119). The activity adopts the main principle of problem-based learning, in which the student-participants are encouraged for thinking their proposed solutions. Those principles are problembased learning is started with real life (Hung et al., 2008) as authentic learning materials (Stepien \& Gallagher, 1993), open-ended questions (Northern Illinois University, n.d.), which need multi-answers (HmeloSilver, 2004) and diversities (Savin-Baden, 2000), case study (Marra et al., 2014) and reactivate learners' prior knowledge (Schmidt, 1983).

The collected data are analyzed in several steps. Firstly, the data are read. Secondly, themes and categories are identified. Thirdly, the classified data based on their themes and categories are interpreted. Fourthly, the findings are connected to the existing theories and studies. The following figure presents several scenes (Figure 1).
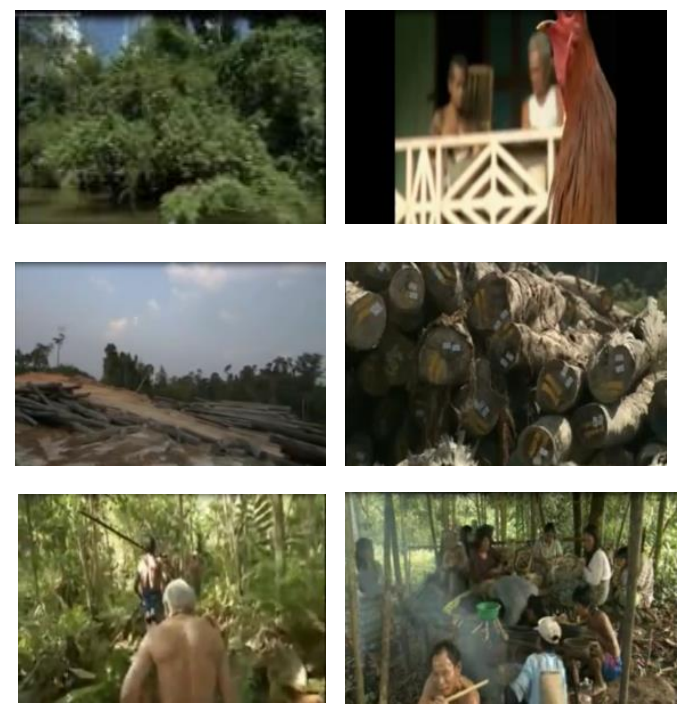

Figure 1. Several Screenshots of the assigned video (Dayak Challenge in the 21st century-cultural displacement, Dayakbaru (2008)

The video illustrates several main aspects. The first is the function of forest for Dayak. For them, forest is home in a complete sense, which means that forests are functioning as their shelters, a place where they find food and medicine. The second is forests devastation is happening. Many loggers come and destroy their land. The companies destroy their farms and houses, 
where they grow vegetables. The fourth is they want to fight back. The fifth is their life is getting worse and it is similar to life or death situation.

\section{RESULTS AND DISCUSSION}

The study aims to explore several students' development issue analysis and problem solving recommendation. The student-participants' responses are stimulated by a vides-based case on Dayak ethnic threatened life because of deforestation activities.

The data analysis show several emerging themes and categories. The studentparticipants' response reveal that they are proposing four solutions for managing lifethreatening issues of Dayak people as endangered indigenous ethnic. Those are caring their environment and culture, involving external agents, building internal community capacity and adapting to the current situation. The detail categories, data dispersion and data grouping is presented in the following table (Table 1).

Table 1. Categories, data dispersion and data grouping

Environment and Culture Care:

Re-planting/planting new trees (S1; S32)/ T11 ; re-vitalizing land (S1)/T1-2; moving to find better forest (S14)/T1-3; strengthening roles of kepala suku in keeping the members' spirit to live (S20)-T1-4; increasing sense of belonging and pride of their indigenous culture (S20)/T15 , building long traditional houses accommodating more people inside (S15)/T16

\footnotetext{
External agents involvement:

Documenting and publishing their threatened life (S1; S14)/T2-1, involving external cared community (outside community awareness) locally, nationally and internationally (S1; S4; S7; S9; S12; S13; S17; S29; S35)/T2-2, finding education opportunities/help from external world (such as government) (S2; S21)/T2-3, understanding/learning government's illegal logging policy and environmental protection and find government protection/law enforcement (S3; S4 ;S9; S16; S32)/T2-4,
}

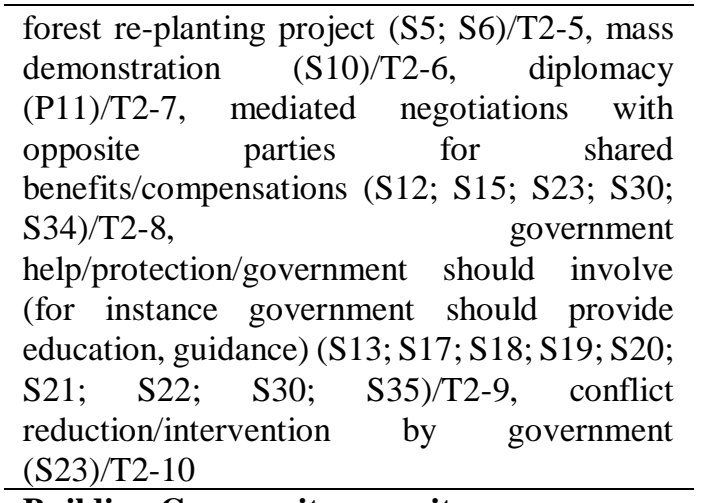

Building Community capacity:

Self-Education (S2)/T3-1, educating the next generation (S11)/T3-2, equipping community self with current skills (for instance industrial revolution) (S8)/T3-3, keeping on fighting, especially understanding ownership legal regulation (S9)/T3-4, developing young indigenous people as custodians (S13)/T3-5, developing stronger community defense/protection system (S16; S17; S28; S30)/T3-6, Kepala suku roles in maintaining ethnic group culture (S20)/T3-7, learning law and state (S24)/T3-8, having indigenous representative for voicing the community needs (S29)/T3-9

\begin{tabular}{l}
\hline Adapting to current situation: \\
\hline Re-orienting perception about outside world \\
(S3)/T4-1, interacting/socializing with external \\
community (S3;S24;S31)/T4-2, understanding \\
globalization principles (S26)/T4-3, learning \\
from other outside community, how they live, \\
their knowledge (S3)/T4-4, changing life and \\
start to adapt to industrial revolution era \\
(S8)/T4-5, starting accepting and using modern \\
technology (S15; S27; S31)/T4-6, \\
understanding reasons of new development \\
(S22)/T4-7, adopting new life style \\
(S22;S25;S27;S33)/T4-8, reducing their \\
dependency on forest (S29)/T4-9, adopting \\
modern school and thinking (S30)/T4-10 \\
\hline
\end{tabular}

Each theme is analyzed and presented in the following discussion section. Several data samples are presented to represent every data grouping.

The data show that the studentparticipants are able to detect the issues and propose various solutions. Their solutions are relevant to the development principles in general perspectives, which can be potentially contribute to indigenous well 
being. The following section presents the samples of data, analysis and relationship with existing studies.

\section{Environment and Culture Care}

The data show that the students believe that indigenous people protection and development can be executed by encouraging them to protect, rejuvenate and revitalize their natural environment and re-structuring their indigenous culture. The following table (Table 2) presents data samples on environment and cultural care. The following data is the authentic response from studentsparticipants.

Table 2. Environment and Culture Care

\begin{tabular}{|c|c|}
\hline Students' Response & Code \\
\hline $\begin{array}{l}\text { "Another thing they can do is to re-plant } \\
\text { the tree, of course they can't do it alone. } \\
\text { So they need help ..."(S1) }\end{array}$ & T1-1 \\
\hline $\begin{array}{l}\text { "...the early step they can get the help } \\
\text { they need to revitalize the land..." (S1) }\end{array}$ & T1-2 \\
\hline $\begin{array}{l}\text { "Last, if the government still has no } \\
\text { action, the Penan should move. Yes, its' } \\
\text { sadden me. But, if they keep maintain } \\
\text { their forest and try to block the loggers or } \\
\text { even the company, they could get } \\
\text { attacked by them..." (S14) }\end{array}$ & T1-3 \\
\hline $\begin{array}{l}\text { "Dayak people have a member who have } \\
\text { job to take care all of the member call } \\
\text { "kepala suku." It's like a chairman in } \\
\text { Dayak tribe. Kepala Suku should tell his } \\
\text { member to keep maintain their own } \\
\text { culture..." (S20) }\end{array}$ & T1-4 \\
\hline $\begin{array}{l}\text { "So Dayak people have to be proud with } \\
\text { their own culture and the government and } \\
\text { citizen have give respect for them." (S14) }\end{array}$ & T1-5 \\
\hline $\begin{array}{l}\text { "...Dayak tribe has a long house and it } \\
\text { called Rumah Lamin. Rather than build } \\
\text { modern house and make sure that every } \\
\text { Penang tribe like it, I think long house is } \\
\text { the best solution for them. I choose this } \\
\text { solution because Penang tribe live with a } \\
\text { group or a big group. They're not } \\
\text { individualism..." (S15) }\end{array}$ & T1-6 \\
\hline
\end{tabular}

The data show that the students are aware that the indigenous people has strong relationship with their natural environment. They suggest that the tribe undertake environment protection and rejuvenation initiatives or perform environmental concern acts (T1-1; T1-2). This indicates that development process requires local people initiatives. The other data show the inseparable connection between indigenous community and nature (Tl-3), which is manifested in their nomadic living culture. This shows role of environment in stimulating migration. Environment degradation causes migration or population mobility (Hugo, 2008). This also confirms that environment influences human capacity to survive (Hugo, 2008). The role of traditional community leadership is analyzed by $S 20-T 1-4$. This indicates the essential role of leadership, especially cultural leader in community development process, as the leader has close interaction with the community, is trusted and nurtured by the community. Thus, the leader has the local community cultural sense and bound. The other data show the importance of community identity (T1-5; T1-6). S14 and $S 15$, in $T 1-5$ and $T 1-6$, view culture as identity which can evoke sense of togetherness/cohesion. This cohesion is the foundation for indigenous people selfprotection and development. The data also show the interlink between community leadership and social cohesion in indigenous community development (inter-connection between $T 1-4$ and $T 1-6, T 1-6$.

The data indicate the interfaces of environment and development. Dayak ethnic life sustainability and security depend largely on their relationship with natural environment. This confirms existing community development projects and community studies which emphasize needs to integrate environment in development and community sustainability. Environment and its biodiversity is resource for human life (Wider, 1991). Loss of biodiversity, water, soil, air pollution, greenhouse and desertification areas (Katsoulakos et al., 2016, p. 509), land degradation (Sakmar et al., 2011), caused by population pressures, development insufficiency and development process (Jalal, 1993) bring about serious environment problems (Katsoulakos et al., 2016, p. 509). Rapid technological evolution and environmentally unethical human behavior are some of many sources causing the devastation of biophysical environment (Watson et al., 2014, p. 7). The competing 
activities of maintaining forest and depletion of natural resources, including agricultural land use degrades environment capacity to sustain human life (Halkos, 2018). Environment stress threatens human security, an essential element in development (Euromodel, n.d.). Today, the need to protect environment in development receives global attention (Lu, n.d.), in which development is viewed from a broader perspective by considering and integrating environment in development management strategy (BTC, 2009; Halkos, 2018; Jalal, 1993; Lu, n.d.), instead of just considering economic factor (Euromodel, n.d.). Thus, the core challenge of sustainable development is progressing economic and business sectors without sacrificing environment and its quality (Adams, 2009). One of environmentally friendly attempt is green development. Several green concepts are developed to respond environment sustainability challenges, including green development (Adams, 2009), green growth (OECD, 2012), green economy (Pan American Health Organization \& WHO, 2013) and integrated environment-development program (Bass et al., 2010; Morris, \& Shore, 2013). Green growth is defined as an approach for fostering economic progress and developing and assuring that natural capital is continually supporting services for well being (OECD, 2011, cited in OECD, 2012, p. 9). Wellprotected and treated environment produces healthy community (Morris, \& Shore, 2013; Pan American Health Organization \& WHO, 2013; Simonis, 1992).

The student- participants' recommendation on indigenous people initiative act to save environment is relevant to development principles. One of development core principle is local community involvement. Local community participation is essential for environment protection and development sustainability (United Nations, 2013a). The indigenous people initiative/act in rejuvenating natural environment can bring about benefits for world food, water and human security. This is because the balanced ecosystem and biodiversity sustain human life in world and culture (Katsoulakos et al., 2016).

The data also reveal that the studentparticipants suggest strengthening culture as a way to protect and develop themselves (T1-5; T1-6). This finding validates studies revealing roles and contribution of culture in development (Iyaji \& Gomment, 2011; Lazareva et al., 2018; Maraña, 2010; Sempere, n.d.). Culture is resource and component of human and sustainable development (Portolés, n.d.), source of identity, innovation and creativity (UNESCO, n.d.). Culture can promote or deter development (Iyaji \& Gomment, 2011; UNESCO, 2012) and provide vehicles for many development aspects: economic, social, environment, and resilientcommunity development (UNESCO, n.d.). Community who is not proud of their culture tends to experience development barriers (Iyaji \& Gomment, 2011).

The data indicate that to protect themselves and develop, indigenous community also needs to be together (T1-6). Social cohesion is an indicator of prosperous community (UNDP, n.d.). Community cohesion is understood as a condition where all people in community live and grow together in harmony (Cohesion and Faiths Unit, 2005), in an integration (LGA, 2004). Social cohesion is indicated by connectedness, social relationship and tendency for doing common good (UNDP, n.d.) which is intervened by culture (UNESCO, n.d.).

The student participant's (S15)/T1-6 thinking of the need of Dayak people to build a long house to live together and being proud of their culture (S14)/T1-5 indicates the need the implementation of cohesive community building. The integrated cohesive community strategy includes: community feel proud of their identity and heritage, all people socialize and share equal rights, upholds values of tolerance and all people respect the aforementioned values (LGA, 2019). It is indicated by a condition with the absence of disparities, inequalities and exclusion and strengthened social 
bonds, interactions and relations (Bureau for Crisis Prevention and Recovery, 2009) and increasing relationship (Idris, 2019).

The data show the student-participant, S20/T1-4, recommends Dayak community leader to fulfill cohesion roles. Leadership and culture can be an integrative tool for indigenous community protection and development. Leaders are influential figures for promoting community cohesion (Cleveland \& Cleveland, 2018; Cohesion and Faiths Unit, 2005; Faunce, 1993; Islam et al., 2020; LGA, 2004, 2019; López et al., 2015; UNDP, n.d.).

\section{External Agents Roles}

The data show that the studentparticipants suggest the important roles of external agents to promote Dayak/indigenous community protection and development. The following table (Table 3) presents several data samples on external agent involvement elicitation.

Table 3. External agents roles

\begin{tabular}{|c|c|}
\hline Students' Response & Code \\
\hline $\begin{array}{l}\text { "...one of many thing that Dayak could } \\
\text { do is to get a documentary and just } \\
\text { document their live and their problem. } \\
\text { Publication can give light to their } \\
\text { problem so that more people can care..." } \\
\text { (S1) }\end{array}$ & $\mathrm{T} 2-1$ \\
\hline $\begin{array}{l}\text { "Second, they can ask for help from } \\
\text { outsiders. Many organization around the } \\
\text { world that against deforestation can help } \\
\text { the Penan tribe to protect their home..." } \\
\text { (S9) }\end{array}$ & $\mathrm{T} 2-2$ \\
\hline $\begin{array}{l}\text { "We can help them to get an education. } \\
\text { We can help them with give them } \\
\text { socialization about the importance of } \\
\text { education..." (S2) }\end{array}$ & $\mathrm{T} 2-3$ \\
\hline $\begin{array}{l}\text { "Second, they can ask help for help from } \\
\text { the outsiders. Many organization around } \\
\text { the world that against deforestation can } \\
\text { help the Penan tribe to protect their } \\
\text { home. This type of organizations can } \\
\text { make the government to ban } \\
\text { deforestation because it can inflict a } \\
\text { financial loss for its country in long } \\
\text { period of time." (S9) }\end{array}$ & $\mathrm{T} 2-4$ \\
\hline $\begin{array}{l}\text { "The Dayak's people needs help to stop } \\
\text { the deforestation. Forest conservation are } \\
\text { required, deforestation needs to cease. } \\
\text { Protecting forest is critical, also restoring } \\
\text { areas that already degraded. We should }\end{array}$ & $\mathrm{T} 2-5$ \\
\hline
\end{tabular}

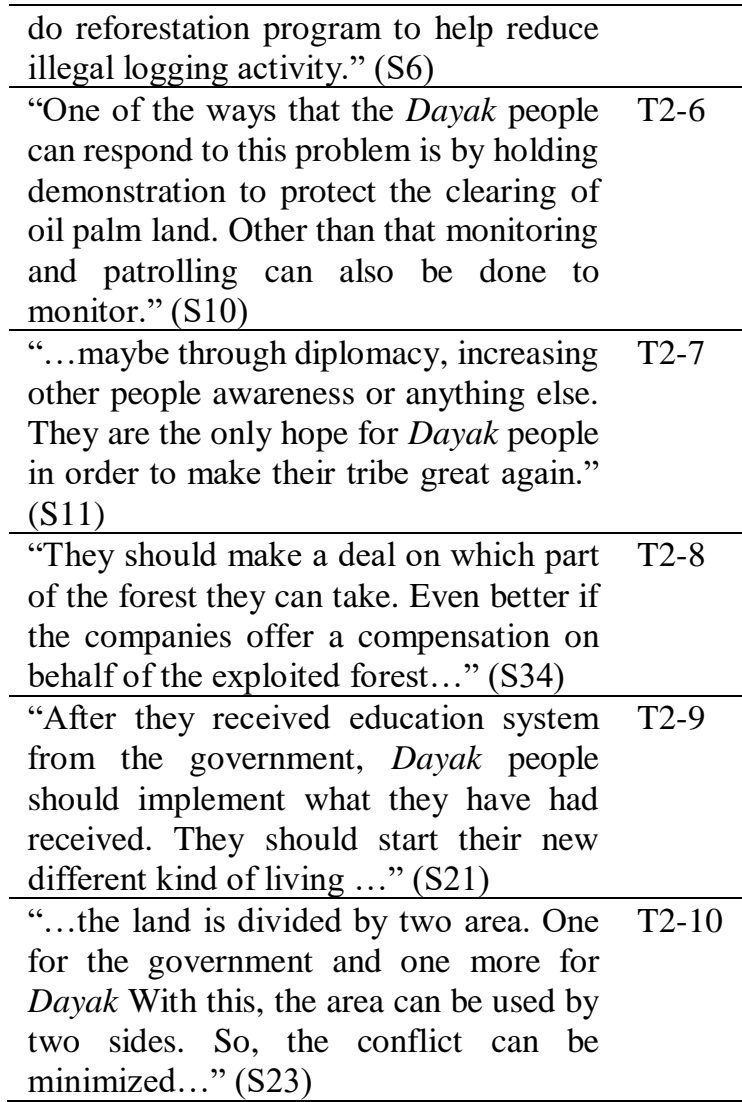

The data demonstrate that the studentparticipants understand that to protect and develop themselves, Dayak indigenous people should find some protection and development assistance. The studentparticipants suggest different external development agents: public community and community-cared organization (T2-1; T2-2; T2-3; T2-4 T2-5; T2-6; T2-7), companies (T2-8) and government (T2-9; T2-10). The student-participants also recommend several forms of development assistance, including reforestation project joint-action (T2-2; T2$5)$, education (T2-3), voicing problems (T24; T2-6), mediation (T2-5), government protection (T2-9; T2-10) and development agreement (T2-8). This indicates the studentparticipants are aware of the development principles of joint-action between targeted community and external development agents (principles of development agency). Some of those development agents are enterprises, NGO, intellectual, researchers, environment organization/community, media and other civil communities (Burns, 2016).

The student-participants' development analysis confirms other studies findings 


\section{ADI SURYANI, SOEDARSO, WAHYUDDIN, MOH. SAIFULLOH, SITI ZAHROK/ Community Development Education: Examining Students' Video-Based Case Analysis on Community Issues, Indigenous Ethnic Protection and Empowerment}

which illuminate the roles of external development agents in facilitating development. The development agents help the community by building collaborative actions to achieve some planned development agenda/goals, set priorities, combat barriers and promote sustainable development (United Nations, 2008). The development agencies are mediating the consensus building and development agreement (Steingass, 2015), keeping peace (Pacheco et al., n.d.) and changing agents (Lunenburg, 2010), intervening development process (Garikipati \& Olsen, 2008) and providing development aids and incentives (Vollmer, 2012). As agents of change, the external parties fulfill roles of providing consultation, training and researching (Lunenburg, 2010). They are also building cooperation with the policy makers since success of change is depending on intercooperation with policy makers (Lunenburg, 2010). Effective agency is determined by empathy, hemophily, relationship, proximity, arrangement, capacity and openness (Lunenburg, 2010).

The student-participant $(S 2 ; S 9)$ analysis of the development agency may refer to role of certain organization, such as NGO. NGO is one of key players in development arena (Tortajada, 2016). As participatory empowerment agent (Banks \& Hulme, 2012), NGO has significant role in development, especially in negotiation, advocacy for claiming human right, peace and environment protection (Tortajada, 2016), providing budget for targeted community with specific development program (Morton, n.d.), planning, implementing and managing specific development program (Morton, n.d.), servicing, facilitating, encouraging and bridging community needs (Banks \& Hulme, 2012) and intervening policy-making (Tortajada, 2016). The other way to assist community development is through CSR program. CSR aims to share productive result, develop closer relationship with community, get talents, undertake technology transfer, environment protection (Ismail, 2009).Thus, it is potentially develop community socially, economically and environmentally (Ismail, 2009).

The data highlight the important role of government in protection and development (T2-9; T2-10). The data specifically focus on government roles in facilitating community education (T2-9) and conflict mediator (T210). Many development studies illuminate government roles and responsibilities in development. Some of government significant roles are legalizing and enforcing development policy (Elias \& Noone, 2011; Hyun, 2006; Polman, n.d.), catalyzing change (Hyun, 2006; van der Waldt, 2016), bridging development (Junli \& Lihua, 2014), forming development allies (Alińska et al., 2018), intervening and collaborating with firms (Alińska et al., 2018) and other agents, such as FAO, ILO (Polman, n.d.), providing financial assistance, such as grants or loans under certain conditions (Alińska et al., 2018; Hyun, 2006; Shah, 2017), transferring knowledge, supporting stability of macro-economic, investing on infrastructure and exercising strong leadership (IFC, 2011), ensuring social security and stabilizing political situation (Hyun, 2006). Musgrave (1959, cited in van der Waldt, 2016) classifies big roles of government into allocator (managing resources for development), distributor (security, equity), regulator (enforcing law), stabilization (fiscal, monetary).

The data demonstrate that it is important for the indigenous people develop agreement $(T 2-8)$ and understand law and regulation on logging and deforestation (T27). The student-participants address the relationship between informed community, law and development. They are also aware of the need to advocate legal empowerment. The data on compensation (T2-8) relates to community-outsiders benefit agreement. This agreement defines companies relationship with the impacted community and their responsibilities (Otto, 2010; Salkin \& Lavine, 2008). Furthermore, this agreement addresses the need of implementing justice and democracy in development. Legal empowerment 
promotes community participation and acknowledges the marginalized community voices, which illuminate gender equity and environmental focus (Golub, 2010), establishing community understanding on law and justice (Pitegoff et al., 2017, 2017; Republic of Rwanda, 2008; Ross, 2010).

The student-participants highlight need of indigenous people to understand their rights (T2-1; T2-3; T2-4; T2-6; T2-9; T2-10), particularly from the perspective of law. They need to understand meaning of property and property (land) right, mechanism for solving conflict (FAO, 2010) and right to development (United Nations, 2013b). This land property right ensures security, guaranties the benefits and uses the resources (FAO, 2010) to protect community livelihood (FAO, 2010). Local people inclusion in development process, ensure justice, democracy and assure no one is left behind (United Nations, 2013a). The data indirectly calls the needs for implementing customary law for protecting indigenous people culture, rights, obligations and traditional knowledge (WIPO, 2016). It addresses access and right to natural resources, land, property, life and knowledge (WIPO, 2016).

The data also reveal the urgency of advocating indigenous people to fight for their interests and needs and increasing their capacity to voice $(T 2-1 ; T 2-2 ; T 2-3 ; T 2-6$; $T 2-7)$. This advocacy enables the community to speak, influence decision making, exercise power ad pressure authorities (Advocacy-The Advocates for Human Rights, n.d.; Barrett et al., 2016). It benefits community since it is raising consciousness, educating community, networking, acting legally (Barrett et al., 2016), helping them to achieve social equity (OECD, 2010), stimulating changes (Fayoyin, 2013; R. Gilbert \& Nelson, 2018; ICMM, n.d.; Inclusion International, 2016; Morton, n.d.; OECD, 2010; Scheunpflug \& McDonnell, 2008; Van Gorkum, 2015). What to do in advocacy are building coalition for shared development vision and goal, ensuring joint-action and maintained togetherness, defining problems, plan and strategies and building effective communication (OECD, 2010). Advocacy utilizes some channels: public education, media, lobbying legislative, influencing business, social media (Advocacy-The Advocates for Human Rights, n.d.).

\section{Building Community Capacity}

The data demonstrate that external development assistance is not the only way to protect the indigenous community. The student-participants suggest the community to increase their internal capacity to protect and develop themselves. Some samples of the data are represented in the following table (Table 4).

Table 4. Building community capacity

\begin{tabular}{|c|c|}
\hline Students' Response & Code \\
\hline $\begin{array}{l}\text { "Dayak people must get an education } \\
\text { because with education we can } \\
\text { understand what we have to do. } \\
\text { Education can make us understand the } \\
\text { law. If we understand the law, we can } \\
\text { enforce the law." (S2) }\end{array}$ & T3-1 \\
\hline $\begin{array}{l}\text { "...one of them is through education. } \\
\text { Dayak people need their next generation } \\
\text { to be smart. They can't keep relying on } \\
\text { other party to protect them...." (S11) }\end{array}$ & T3-2 \\
\hline $\begin{array}{l}\text { "I think Dayak people should do some } \\
\text { changes in doing their life. Because of } \\
\text { industry revolution that is not friendly } \\
\text { with people that not follow it. So, I think } \\
\text { Dayak people should start their changes } \\
\text { with doing new activity that teach Dayak } \\
\text { people to follow industrial revolution..." } \\
\text { (S8) }\end{array}$ & T3-3 \\
\hline $\begin{array}{l}\text { "...the Penan tribe must fight for their } \\
\text { legal recognition and ownership. They } \\
\text { can get if there is a lot of organization that } \\
\text { help them to get their legal } \\
\text { recognition..." (S9) }\end{array}$ & T3-4 \\
\hline $\begin{array}{l}\text { "The young one should be the custodians } \\
\text { for their tribe and their future. They } \\
\text { should know how important it is to keep } \\
\text { their tribe..."(S13) }\end{array}$ & T3-5 \\
\hline $\begin{array}{l}\text { "The people can activate guard post at } \\
\text { several accesses and carry out joint } \\
\text { operations in Dayak's forest. The people } \\
\text { also be assertive towards foreigners who } \\
\text { come by checking identity and } \\
\text { licensing." (S16) }\end{array}$ & T3-6 \\
\hline $\begin{array}{l}\text { "Dayak people have a member who have } \\
\text { job to take care all of the member call } \\
\text { "kepala suku." It's like a chairman in } \\
\text { Dayak tribe. Kepala Suku should tell his } \\
\text { member to keep maintain their own } \\
\text { culture..." (S20) }\end{array}$ & $\begin{array}{l}\text { T1-4; } \\
\text { T3-7 }\end{array}$ \\
\hline $\begin{array}{l}\text { "... and also to learn about the law and the } \\
\text { states so that they would be able to }\end{array}$ & T3-8 \\
\hline
\end{tabular}


change how the government treat local native tribes and their land (S24)

"...Secondly, there should be a Penan T3-9 people representative so they can be more vocal about their tribe struggle..." (S29)

The data indicate that the studentparticipants understand that to be well protected and developed, they should have inner will and efforts. Different student proposes different approaches to build community capacity, such as through education (T3-1; T3-2; T3-5), leadership and collaborative co-leadership (T1-4; T3-7; T3$9)$, security (T3-4; T3-6). These approaches are interrelated, since community building capacity requires integrated efforts. This capacity is needed for the community to survive, perform and renew (Ubels et al., 2010). Community development is important since it increases individual and community well being, skills, sense of community and chance for participation as the basic of contribution in local governance and create their own living community (Greater Shepparton, 2010).

The student-participants' analysis is relevant to findings of several studies on community capacity building. Community capacity to respond and work with their own issues is addressed by many studies (Atkinson \& Willis, n.d.). Community development capacity building is not only concerning with training aspect, but also supportive leadership, education, established public system, community voicing, services delivery (UNDP, 2008). Social and human capital improvement is the emphasis of capacity building (Merino \& Carmenado, 2012; Wendel et al., 2009). Community development occurs when the community uses their community internal asset and resources and performs an effort and they become the basis of community regeneration (McKnight \& Kretzmann, 1990).

The student-participants propose education as a means to develop themselves and equip skills for developing their own selves (T3-1; T3-2; T3-3; T3-5; T3-8). This indicates that by learning, the community can protect and achieve betterment. Skill, competency, learning and ability are needed in improving capacity (Müller et al., 2015). Several other elements are social relations, systems for community dialog, society participation, value system and learning culture (Wendel et al., 2009), problem solving, skills, utilizing resources, being committed (Meyer, 1994, cited in Chaskin, 1999). Continuous learning is one of determinants in building capacity. Through learning, certain community can renew themselves continuously. Capacity development also means individual, organizations and societies strengthening process which occurs based on development objectives over time (Kieffer \& Reischmann, 2004; UNDP, 2008, 2009). It is a continuous process. Thus, it needs to be improved over time (Ubels et al., 2010). Capacity needed to develop includes adaptive and renew, commit and participate, balance variety, develop relationship, undertaking technical tasks (Baser \& Morgan, 2008, cited in Bester, 2015, p. 264).

\section{Building Adaptive Capacity}

Several data address the need to adapt to current demand and situation. These data support the indigenous community to accept changes and renew themselves to survive. The following table display several data samples on adapting and renewing aspect.

Table 5. Building adaptive capacity

\begin{tabular}{|c|c|}
\hline Students' Response & Code \\
\hline $\begin{array}{l}\text { "...why they need to meet with the more } \\
\text { developed community and improve their } \\
\text { perception about living outside the } \\
\text { forest..." (S3) }\end{array}$ & $\mathrm{T} 4-1$ \\
\hline $\begin{array}{l}\text { "So, what I suggest for the people of } \\
\text { Dayak is to learn to interact with outside } \\
\text { people and also to learn about law and } \\
\text { state..." (S24) }\end{array}$ & $\mathrm{T} 4-2$ \\
\hline $\begin{array}{l}\text { "Dayak tribe should know about } \\
\text { globalization. So, they are not back ward } \\
\text { and still alive in any condition..." (S26) }\end{array}$ & $\mathrm{T} 4-3$ \\
\hline $\begin{array}{l}\text { "...any by meeting new people they can } \\
\text { transfer each other the knowledge } \\
\text { Penang tribe have with the more } \\
\text { developed community..." (S3) }\end{array}$ & $\mathrm{T} 4-4$ \\
\hline
\end{tabular}




\begin{tabular}{|c|c|}
\hline $\begin{array}{l}\text { "So...I think Dayak people should start } \\
\text { their changes with doing new activity that } \\
\text { teach Dayak people to follow industry } \\
\text { revolution..." (S8) }\end{array}$ & \\
\hline $\begin{array}{l}\text { "..they must move forward. Learn to be a } \\
\text { modern people. Face the world with } \\
\text { technology and live with people apart } \\
\text { from their tribe." (S31) }\end{array}$ & T4-6 \\
\hline $\begin{array}{l}\text { "The Dayak people must examine the } \\
\text { reasons why people cutting down their } \\
\text { forest. Because in my opinion, there must } \\
\text { be a strong (positive) reason..." (S22) }\end{array}$ & T4-7 \\
\hline $\begin{array}{l}\text { "Changing here means adaptation to the } \\
\text { new environment or new way of life. } \\
\text { They can learn new ways of life from } \\
\text { time to time..." (S22) }\end{array}$ & T4-8 \\
\hline $\begin{array}{l}\text { "They could learn how to farm or } \\
\text { cultivate their food, so they could survive } \\
\text { on a harsh condition when the forest can } \\
\text { no longer provide food for them..." (S29) }\end{array}$ & T4-9 \\
\hline $\begin{array}{l}\text { "I think the next solution, Dayak people } \\
\text { should start to build modern school in his } \\
\text { residence in order to follow industrial } \\
\text { revolution." (S30) }\end{array}$ & T4-10 \\
\hline
\end{tabular}

The data show that the studentparticipants recommend adaptation as one of several solutions. They argue that to survive, the indigenous community should start adopting new learning ways. This adaptive process is undertaken through several dimensions: changing perception (T4-1) and understanding globalization meaning (T4-3), interacting with outside people (T4-2; T4-4), learning new skills (T4-5; T4-6; T4-9), understanding reasons behind adaptation forces (T4-7), changing living ways (T4-8) and investing education for long term (T410). The data demonstrate that the studentparticipants understand the relationship between community development and community adaptive capacity. The studentparticipants illuminate the importance to learn from others, adapt to the new changing environment and adopt technology and information system to survive and develop.

This adaptation need is consistent with studies on roles of community adaptive capacity on community development. Marginalized and vulnerable community faces complex issue, especially relating to ecological changes (CARE Climate Change, 2015; Rodríguez et al., 2018; Syafruddin et al., 2018), as the consequences of human activities which harm environment sustainability (Meffe et al., 2002). Thus, they need to adapt to current changes. Adaptation is defined as human adjustment to certain actual stimuli causing hazard and opportunities (Smit \& Wandel, 2006). Community capacity to adapt means community ability to adjust, minimize the harmful effect, manage the impact and take the benefits of changes (Jones et al., 2010; Smit \& Wandel, 2006), their capacity to respond to changing situation in spite of their limitations on social-economicpolitical structures (Smit \& Wandel, 2006).

Successful adaptation is influencing many dimensions of people life. Community adaptive efforts are impacting on community survival (Smit \& Wandel, 2006), well being (Newman, 2013) and resiliency (Maguire \& Cartwright, 2008; Newman, 2013), food sources and selection (Beckerman et al., 2010), develop (Jones et al., 2010), uncertainty management and foresight (Beck et al., 2002). Community adaptive capacity is determined by economic resource, technology, equity, institution, skills and information (Smit \& Wandel, 2006), internal factors (technical skills, transfer skills, taking benefits from opportunities), education, empowerment, changing perception and external aspects (support, social conflict) (Syafruddin et al., 2018), access to information, knowledge, self-efficacy, flexible and future-oriented decision making (CARE Climate Change, 2015), diversification capacity, risk reduction strategies, support, social mobilization (CARE Climate Change, 2015), strong traditional knowledge, social networks, resources, self-sufficiency (Warrick, 2012) and asset, innovation, knowledge, institution, flexibility (Jones et al., 2010).

Adaption process relates strongly to community learning capacity. This is also indicated by the student-participants ( $S 8$; S8; S31; S29; S30). Adaptive capacity embodied community capacity to learn something (Maguire \& Cartwright, 2008; Newman, 2013; Rodríguez et al., 2018; Shrestha et al., 2009). Adaptive capacity resulted in community resiliency 
encouraging community to return to the previous condition, recovery or bounce back to the original state and transformation or adapting to the changes (Maguire \& Cartwright, 2008).

\section{Community Development Analysis Modle}

The study finds that case-study video integrated with students' active learning can stimulate student-participants' development analysis, particularly Dayak indigenous community issues, protection and development. To promote the indigenous ethnic protection and development, the student-participants recommends four main solutions. The first solution is the environment and culture care. This includes environment integration into development, indigenous people initiative act, protecting environment, strengthening culture, social cohesion and developing strong community leadership. What indigenous community needs to build themselves? Based on aboriginal case study, the community requires several elements: leadership, participation, community structure, resources, relationship with others, external assistance, understanding the causes, knowledge/skills and sense of community (Fletcher et al., 2008), power, resource mobilization (Aref et al., 2010). Several facilitating aspects in indigenous people development include encouraging community autonomy, embedding culture, developing leaders, empowering local people, exercising good governance, trusting relationship, flexible development times and utilizing community-based approach (Morley, 2015, p. 4). The second solution is involving external community in development. This includes government roles in protection and development, development agreement, legal empowerment, nongovernment role, indigenous people advocacy. The indigenous people cannot develop/progress by themselves. They need some helps and cooperation with other external people/community/organization or external world through cooperation (Blackwell-Moore \& O'Brien, 2017; United
Nations, 2008). The third solution is building community capacity, including community education, supportive leadership, security system and young people education. The fourth is adaptive capacity including adapting new life, learning style, interacting with outside world, understanding globalization, learning technology, interacting with outside people, investing education and learning new skills.

Community Development Education by Integrating Video

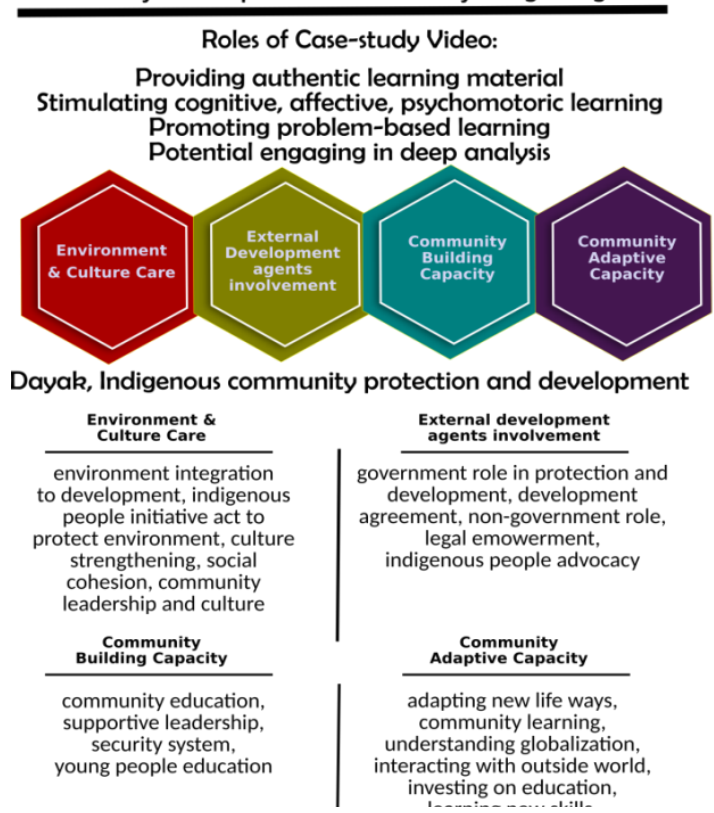

Figure 2. Students' Community Development Analysis Model

A case study video leverages students' learning on community issues, protection and development through several ways. Firstly, it presents authentic learning material. Secondly, it generates affective, cognitive and psychomotoric learning aspects. Thirdly, it stimulates the studentparticipants engage in problem solving learning. Fourthly, it potentially stimulates the student-participants to engage in deep analysis. The result of the studentparticipants' analysis is illustrated in the figure 2 .

\section{CONCLUSION}

Case study video is one of many educational tool for promoting student 
analysis and problem solving capacity. Video offers authentic material and brings reality into classroom. Thus, the students may feel being there. This study finds that a case study video on life threatened of Dayak ethnic stimulates students' awareness on indigenous community issues and condition. The study reveals that the students propose four main solutions to Dayak life issues. The first is environment and culture care. This covers several actions, such as integrating environment into development, initiating environment protection, strengthening culture, increasing social cohesion and developing community leadership and culture. The second solution is namely external community inclusion. In this solution, government and non government institutions roles are expected, in addition to developing development agreement, legal empowerment and advocacy. The third solution is building community capacity through community education, supportive leadership, security system and young people education. The fourth solution is building community adaptive capacity through adapting new life ways, learning new skills, understanding globalization, investing on education for long term.

\section{REFERENCES}

Acharya, S., Manohar, P., \& Wu, P. (2017). Using Case Study Videos as an Effective Active Learning Tool to Teach Software Development Best Practices. Systematics, Cybernetics, and Informatics, 15(3), 70-75.

Adams, W. M. (2009). Green Development. Environment and sustainability in a developing world (3rd ed.). Routledge.

Advocacy-The advocates for human rights. (n.d.).

https://www.theadvocatesforhumanrig hts.org

Alińska, A., Filipiak, B. Z., \& Kosztowniak, A. (2018). The Importance of the Public Sector in Sustainable Development in Poland. Sustainability, 10(3278), 1-24. https://doi.org/doi:10.3390/su1009327 8
Aljamal, Y., Saleem, H., Prabhakar, N., Abhishek, C., \& Farley, D. R. (2020). Group Video Feedback is an Effective and Efficient Tool for Enhancing Skills of Surgical Interns. Journal of Surgical Research, 251, 248-253. https://doi.org/10.1016/j.jss.2020.01. 021

Altıok, S., Başer, Z., \& Yükseltürk, E. (2019). Enhancing metacognitive awareness of undergraduates through using an e-educational video environment. Computers \& Education, 139, 129-145. https://doi.org/10.1016/j.compedu.20 19.05.010

Aref, F., Redzuan, M., \& Gill, S. S. (2010). Community Capacity Building: A Review of its Implication in Tourism Development. Journal of American Science, 6(1), 172-180.

Argaw, A. S., Haile, B. B., Ayalew, B. T., \& Kuma, S. G. (2017). The Effect of Problem Based Learning (PBL) Instruction on Students' Motivation and Problem Solving Skills of Physics. EURASIA Journal of Mathematics Science and Technology Education, 13(3), 1305-8223. https://doi.org/DOI 10.12973/eurasia.2017.00647a

Atkinson, R., \& Willis, P. (n.d.). Community Capacity Building - A Practical Guide (Paper No. 6; Housing and Community Research Unit, pp. 115). University of Tasmania.

Bamber, J., Owens, S., Schonfeld, H., Ghate, D., \& Fullerton, D. (2010). Effective community development programmes: A review of the international evidence base (CES Evidence Review, pp. 1-101). The Centre for Effective Services. http://hdl.handle.net/10147/298996

Banks, N., \& Hulme, D. (2012). The role of NGOs and civil society in development and poverty reduction (BWPI Working Paper No. 171). The University of Manchester. www.manchester.ac.uk/bwpi

Barrett, J. B., van Wessel, M., \& Hilhorst, D. (2016). Advocacy for Development. 
Effectiveness, Monitoring and Evaluation (pp. 5-91). Wageningen University.

Bass, S., Annandale, D., Van Binh, P., Dong, T. P., Nam, H. A., Oanh, L. T. K., Parsons, M., Van Phuc, N., \& Van Trieu, V. (2010). Integrating environment and development in Viet Nam. Achievements, challenges and next steps (No. 2; Environmental Governance Series, pp. 1-58). IIED \& UNDP.

Beck, M. B., Fath, B. D., Parker, A. K., Osidele, O. O., Cowie, G. M., Rasmussen, T. C., Patten, B. C., Norton, B. G., Steinemann, A., Borrett, S. R., Cox, D., Mayhew, M. C., Zeng, X. Q., \& Zeng, W. (2002). Developing a Concept of Adaptive Community Learning: Case Study of a Rapidly Urbanizing Watershed. Integrated Assessment, 3(4), 299-307.

Beckerman, A., Petchey, O. L., \& Morin, P. J. (2010). Adaptive foragers and community ecology: linking individuals to communities and ecosystems. Functional Ecology, 24, $1-6$. https://doi.org/doi: 10.1111/j.1365-2435.2009.01673.x

Bello-Bravo, J., \& Baoua, I. (2012). Animated videos as a learning tool in developing nations: A pilot study of three animations in Maradi ad surrounding areas in Niger. The Electronic Journal on Information Systems in Developing Countries, 55(6), 1-12.

Beloufa, S., Cauchard, F., Vedrenne, J., Vailleau, B., Kemeny, A., Mérienne, F., \& Boucheix, J.-M. (2019). Learning eco-driving behaviour in a driving simulator: Contribution of instructional videos and interactive guidance system. Transportation Research Part F, 61, 201-216. https://doi.org/10.1016/j.trf.2017.11.0 10

Beltrán, J. (2000). Indigenous and Traditional Peoples and Protected Areas. Principles, Guidelines and
Case Studies (World Commission on Protected Areas No. 4; Best Practice Protected Area Guidelines Series, pp. 1-123). IUCN-The World Conservation Union.

Bester, A. (2015). Capacity development (Final Draft No. QPCR2016; Study on Capacity Development, pp. 1-33). The United Nations Department for Economic and Social Affair.

Biard, N., Cojean, S., \& Jamet, E. (2018). Effects of segmentation and pacing on procedural learning by video. Computers in Human Behavior, 89, 411-417. https://doi.org/10.1016/j.chb.2017.12 .002

Blackwell-Moore, L., \& O’Brien, K. (2017). Achieving Equitable Community Development: Creating a restorative trauma-informed approach in environmental community development organizations (pp. 224). Groundwork.

Brame, C. J. (2016). Effective Educational Videos: Principles and Guidelines for Maximizing Student Learning from Video Content. CBE-Life Sciences Education, 15(es6), 1-6.

Bravo, E., Amante, B., Simo, P., \& Enache, M. (2011). Video as a new teaching tool to increase student motivation. 638-642. https://doi.org/doi: 10.1109/EDUCON.2011.5773205

Bryan, L. A., \& Recesso, A. (2006). Promoting Reflection among Science Student Teachers using a Web-based Video Analysis Tool. Journal of Computing in Teacher Education, 23(1), 31-39.

BTC. (2009). The environment and development. A view of 30 development projects (pp. 9-111). Belgan Development Agency.

Bureau for Crisis Prevention and Recovery. (2009). Community Security and Social Cohesion Towards a UNDP Approach. United Nations Development Programme. 
Burke, S. C., Snyder, S., \& Rager, R. C. (2017). An assessment of faculty usage of YouTube as a teaching resource. The International Journal of Allied Sciences and Practice, 7(1), 1-8.

Burns, T. R. (2016). Sustainable development: Agents, systems and the environment. Current Sociology Review, 64(6), $875 \quad-906$. https://doi.org/DOI: $10.1177 / 0011392115600737$

CARE Climate Change. (2015). Community Based Adaptation: An empowering approach for climate resilient development and risk reduction (pp. 18). CARE Climate Change.

Carmichael, M., Reid, A.-K., \& Karpicke, J. D. (n.d.). Assessing the Impact of Educational Video on Student Engagement, Critical Thinking and Learning: The Current State of Play. Sage Publishing. www.sagepublishing.com

Cavaye, J. (2001). Rural Community Development -New Challenges and Enduring Dilemmas. The Journal of Regional Analysis \& Policy, 32(2), 109-124.

Central Land Council. (2012). Our Projects, Our Way. Community Development Program [Monitoring Report]. Central Land Council.

Chan, W. M. (2014). Video Podcasting as a Supplementary Language Learning Tool - A Study of Its Use, Student Access and Perceptions. Electronic Journal of Foreign Language Teaching, 11(1), 183-206.

Charalambous, C. Y., Philippou, S., \& Olympiou, G. (2018). Reconsidering the use of video clubs for studentteachers' learning duringfield placement: Lessons drawn from a longitudinal multiple case study. Teaching and Teacher Education, 74, 49-61.

https://doi.org/10.1016/j.tate.2018.04. 002

Chaskin, R. J. (1999). Defining Community Capacity: A Framework and Implications from a Comprehensive Community Initiative. Urban Affairs
Association Annual Meeting, Fort Worth, 1-40.

Chen, G. (2020). A visual learning analytics (VLA) approach to video-based teacher professional development: Impact on teachers' beliefs, selfefficacy, and classroom talk practice. Computers \& Education, 144(103670).

https://doi.org/10.1016/j.compedu.20 19.103670

Chiarenza, G. (2013). Current Challenges and New Pathways for Community Development in Indian Country (Volume. 25, Number 2; Community Investments, pp. 1-8). Federal Reserve Bank of San Francisco.

Chin, C., \& Chia, L.-G. (2008). ProblemBased Learning Tools (The Science Teacher, pp. 44-49).

Christiansen, E. T., Kuure, L., Mørch, A., \& Lindström, B. (2013). Problem-based learning for the 21st century. New Practices and Learning Environments. Aalborg Universitet.

Cleveland, M., \& Cleveland, S. (2018). Building Engaged Communities-A Collaborative Leadership Approach. Smart Cities, 1, 155-162. https://doi.org/doi:10.3390/smartcitie s1010009

Cohesion and Faiths Unit. (2005). Community Cohesion: Seven Steps A Practitioner's Toolkit. Office of the Deputy Prime Minister.

Community Development. (n.d.). Coming Up with the Money. Five Principles for Launching a Successful Community Development Initiative. Federal Reserve Bank of St Louis. stlouisfed.org/communitydevelopment

Community Investment. (2012). $A n$ Integrated Approach to Community Development (2012/13; pp. 5-31). Community Development Department, Federal Reserve Bank of San Francisco. www.frbsf.org

Coyne, E., Frommolt, V., Rands, H., Kain, V., \& Mitchell, M. (2018). Simulation videos presented in a blended learning platform to improve Australian 
nursing students' knowledge of family assessment. Nurse Education Today, 66, 96-102. https://doi.org/10.1016/j.nedt.2018.04. 012

Coyne, E., Rands, H., Frommolt, V., Kain, V., Plugge, M., \& Mitchell, M. (2018). Investigation of blended learning video resources to teach health students clinical skills: An integrative review. Nurse Education Today, 63, 101-107.

https://doi.org/10.1016/j.nedt.2018.01. 021

Cruse, E. (2006). Using Educational Video in the Classroom: Theory, Research and Practice.

Dayakbaru. (2008). Dayak Challenge in the 21 st century-cultural displacement. https://m.youtibe.com/watch?v=GNA 9PTe-pzg

De Graaff, E., \& Kolmos, A. (2003). Characteristics of Problem-Based Learning. Int. J. Engng Ed., 19(5), 657-662.

Delello, J. A., McWhorter, R. R., \& Camp, K. M. (2015). Using Social Media as a Tool for Learning: A MultiDisciplinary Study. International $\mathrm{Jl}$. on E-Learning, 14(2), 163-180.

Dudas, K., \& Wheeler, J. (2020). Faculty Reenactment Videos as a Tool in Simulation Debriefing. Clinical Simulation in Nursing, 40, 25-30. https://doi.org/10.1016/j.ecns.2019.11 .007

Eady, M. J. ., \& Lockyer, L. (2013). Tools for learning: technology and teaching strategies. In Learning to Teach in the Primary School. Queensland University of $\mathrm{T}$ echnology. http://ro. uow.edu.au/asdpapers/403

Elias, S., \& Noone, C. (2011). The Growth and Development of the Indonesian Economy. Bulletin, 33-44.

Ellis, R., \& Childs, M. (1999). The effectiveness of video as a learning tool in on-line multimedia modules. Journal of Educational Media, 24(3).
Eng, C. S. (n.d.). Problem based learningeducational tool or philosophy. https://www.tp.edu.sg

Euromodel. (n.d.). Environment and Development. Euromodel.

Excellence in social responsibility. Community development (SR-CDv1.0; A Framework for Responsible Exploration, pp. 1-16). (n.d.).

Fahrurozi, S. K., Maryono, D., \& Budiyanto, C. (2017). The Development of Video Learning to Deliver a Basic Algorithm Learning. Indonesian Journal of Informatics Education, 1(2), $\quad$ 49-56. http://dx.doi.org/10.20961/ijie.v1i2.1 2446

FAO. (2010). Land and Property Rights. Junior Farmer Field and Life School - Facilitator's guide (pp. 1-50). Food and Agriculture Organization of the United Nations.

Faunce, R. A. (1993). Comparison of leadership styles and team cohesion [Thesis, Ithaca College]. http://digitalcommons.ithaca. edu/ic_theses

Fayoyin, A. (2013). Advocacy as a Strategy for Social Change: A Qualitative Analysis of the Perceptions of UN and Non-UN Development Workers. J Soc Sci, 35(2), 181-193.

Fletcher, F., McKennitt, D., \& Baydala, L. (2008). Community Capacity Building: An Aboriginal Exploratory Case Study. Pimatisiwin: A Journal of Aboriginal and Indigenous Community Health, 5(2), 9-32.

Forbes, H., Oprescu, F. I., Downer, T., Phillips, N. M., McTier, L., Lord, B., Barr, N., Alla, K., Bright, P., Dayton, J., Simbag, V., \& Visser, I. (2016). Use of videos to support teaching and learning of clinical skills in nursing education: A review. Nurse Education Today, 42, 53-56. http://dx.doi.org/10.1016/j.nedt.2016. 04.010

Garikipati, S., \& Olsen, W. (2008). The role of agency in development planning 
and the development process. Introduction to the Special Issue on Agency and Development. International Development Planning Review, 30(4), 327-338. https://doi.org/DOI: $\quad$ 10.3828/idpr .30 .4 .1

Gilbert, A., \& Bowden, R. (2017). Image and video mining through online learning. Computer Vision and Image Understanding, $\quad 158, \quad 72-84$. http://dx.doi.org/10.1016/j.cviu.2017. 02.001

Gilbert, R., \& Nelson, J. (2018). Advocating Together for the SDGs - How civil society and business are joining voices to change policy, attitudes and practices (pp. 5-43). Harvard Kennedy School.

Golub, S. (2010). What is Legal Empowerment? An Introduction (Legal Empowerment) [Working Papers]. International Development Law Organization.

Gon, S., \& Rawekar, A. (2017). Effectivity of E-Learning through Whatsapp as a Teaching Learning Tool. MVP Journal of Medical Sciences, 4(1), 19-25. https://doi.org/DOI: 10.18311/mvpjms/2017/v4i1/8454

Gorghiu, G., Drăghicescu, L. M., Cristea, S., Petrescu, A.-M., \& Gorghiu, L. M. (2015). Problem-Based Learning - An Efficient Learning Strategy In The Science Lessons Context. Procedia Social and Behavioral Sciences, 191, 1865 - 1870. https://doi.org/doi: 10.1016/j.sbspro.2015.04.570

Greater Shepparton. (2010). Community Development Framework (pp. 5-35). Greater Shepparton.

Green, J. L., Suresh, V., Bittar, P., Ledbetter, L., Mithani, S. K., \& Allori, A. (2019). The Utilization of Video Technology in Surgical Education: A Systematic Review. Journal of Surgical Research, 235, 171-180. https://doi.org/10.1016/j.jss.2018.09.0 15

Greenberg, A. D., \& Zanetis, J. (2012). The Impact of Broadcast and Streaming Video in Education (pp. 3-39). Cisco
Systems

Inc.

www.cisco.com/go/offices

Gromik, N. A. (2012). Cell phone video recording feature as a language learning tool: A case study. Computers \& Education, 58, 223230.

https://doi.org/doi:10.1016/j.comped u.2011.06.013

Guo, R. X. (n.d.). The Use of Video Recordings as an Effective Tool to Improve Presentation Skills (pp. 92101). https://core.ac.uk

Habes, V., Jepma, P., Parlevliet, J. L., Bakker, A., \& Buurman, B. M. (2020). Video-based tools to enhance nurses' geriatric knowledge: A development and pilot study. Nurse Education Today. https://doi.org/10.1016/j.nedt.2020.1 04425

Halkos, G. (2018). Environment and Sustainable Development: Introduction (Editorial). Int. J. Global Environmental Issues, 17(2/3), 111116.

Hartman, K. B., Moberg, C. R., \& Lambert, J. M. (n.d.). Effectiveness of problembased learning in introductory business courses. Journal of Instructional Pedagogies, 1-13.

Hill, R. y, Cullen-Unsworth, L. C., Talbot, L. D. ., \& McIntyre-Tamwoy, S. (2011). Empowering Indigenous peoples' biocultural diversity through World Heritage cultural landscapes: a case study from the Australian humid tropical forests. International Journal of Heritage Studies, 17(6), 571-591. http://dx.doi.org/10.1080/13527258.2 011.618252

Hmelo-Silver, C. E. (2004). Problem-Based Learning: What and How Do Students Learn? Educational Psychology Review, 16(3), 235-266.

Hmelo-Silver, C. E., \& Barrows, H. S. (2006). Goals and Strategies of a Problem-based Learning Facilitator. The Interdisciplinary Journal of Problem-Based Learning, 1(1), 2139. http://dx.doi.org/10.7771/15415015.1004 
Hooker, J. (2005). Indigenous Inclusion/Black Exclusion: Race, Ethnicity and Multicultural Citizenship in Latin America. J. Lat. Amer. Stud, 37, 285-310. https://doi.org/doi:10.1017/S0022216 X05009016

Hugo, G. (2008). Migration, Development and Environment (No. 35; IOM Migration Research Series, pp. 5-53). International Organization for Migration.

Hung, W., Jonassen, D. H., \& Liu, R. (2008). Problem-based learning. In Handbook of Research on Educational Communications and Technology. Routledge.

Hurtubise, L., Martin, B., Gilliland, A., \& Mahan, J. (2013). To Play or Not To Play: Leveraging Video in Medical Education. Journal of Graduate Medical Education, 13-18. https://doi.org/DOI:

http://dx.doi.org/10.4300/JGME-0501-32

Hyun, O.-S. (2006). The Role of Government in Economic Development. Korea's Economic Development \& Economic Crisis Management.

ICMM. (n.d.). Community Development Toolkit (pp. 5-220). International Council on Mining and Metals.

Idris, I. (2019). Community cohesion projects to prevent violent extremism (Knowledge. Evidence and Learning for Development, pp. 1-12).

IFC. (2011). International finance institution and development through the private sector [A joint report]. International Finance Corporation.

Inclusion International. (2016). SelfAdvocacy for Inclusion: A global report. University of East London.

Islam, M. R., Wahab, H. A., \& Anggum, L. ak. (2020). The influence of leadership quality towards community cohesion in Iban community in Malaysia. Heliyon, 6(e03370). https://doi.org/10.1016/j.heliyon.2020 .e03370
Ismail, M. (2009). Corporate social responsibility and its role in community development: An international perspective. The Journal of International Social Research, 2(9), 199-209.

Iyaji, A., \& Gomment, T. I. (2011). Culture and Development: An Exposition of the Interconnectivity (A Review Article). Current Research Journal of Social Sciences, 3(2), 50-53.

Jalal, K. F. (1993). Sustainable development, environment and poverty nexus (pp. 1-19). Asian Development Bank.

Jones, L., Ludi, E., \& Levine, S. (2010). Towards a characterisation of adaptive capacity: a framework for analysing adaptive capacity at the local level (pp. 1-8) [Background Note]. Overseas Development Institute. www.odi.org.uk/50years

Junli, Y., \& Lihua, C. (2014). Roles of Government Coordinated Regional Development in China. International Journal of Business and Social Science, 5(6), 225-228.

Katsoulakos, N. M., Misthos, L. M. N., Doulos, I. G., \& Kotsios, V. S. (2016). Environment and Development. In Environment and Development. Basic principles, human activities and environmental implications. Elsevier.

Kieffer, E. C., \& Reischmann, J. (2004). Contributions of Community Building to Achieving Improved Public Health Outcomes (pp. 1-33) [Final Report].

Kosel, B., Celinšek, D., Kuštrin, I., Djurić, M., Jarc, M., Vukadinović, N., Vičič, Š. G., \& Jurković, V. (2005). Guide to Problem-Based Learning. PBL within the Context of ESP (pp. 1-78). Slovene Association of LSP Teachers.

Kotsougiani, D., Hundepool, C. A., Bulstra, L. F., Shin, D. M., Shin, A. Y., \& Bishop, A. T. (2016). The learning rate in three dimensional high definition video assisted microvascular anastomosis in a rat model. Journal of Plastic, 
Reconstructive \& Aesthetic Surgery, 69, $1528 \mathrm{e} 1536$. http://dx.doi.org/10.1016/j.bjps.2016. 08.001

Kuhn, C., Zlatkin-Troitschanskaia, O., Brückner, S., \& Saas, H. (2018). A new video-based tool to enhance teaching economics. International Review of Economics Education, 27, 24-33.

https://doi.org/10.1016/j.iree.2018.01. 007

Kusumatuty, A. J., Baedhowi, \& Murwaningsih, T. (2018). The Implementation of Problem Based Learning (PBL) Based E -Book t o Improve The Learning Outcome of Vocational High School (VHS) Students. International Journal of Educational Research Review, 103110. https://doi.org/orcid.org/00000002-9147-7618

Layona, R., Yulianto, B., \& Tunardi, Y. (2017). Authoring Tool for Interactive Video Content for Learning. Procedia Computer Science, 116, 37-44. https://doi.org/10.1016/j.procs.2017.1 0.006

Lazareva, G. I., Efremova, L. A., Rusetskaya, E. A., Ulibina, L. K., \& Okorokova, O. A. (2018). The Role of Culture in the Development of Society and the Opportunities to Finance It in Russia. Journal of History Culture and Art Research, 7(2), 72-86. https://doi.org/DOI:

10.7596/taksad.v7i2.1583

Lehmann, R., Seitz, A., Bosse, H. M., Lutz, T., \& Huwendiek, S. (2016). Student perceptions of a video-based blended learning approach for improving pediatric physical examination skills. Annals of Anatomy, 208, 179-182. http://dx.doi.org/10.1016/j.anat.2016. 05.009 0940-9602/@ 2016 Elsevier $\mathrm{GmbH}$. All rights $r$

LGA. (2004). Community cohesion-an action guide. Guidance for local authorities (LGA Code F/EQ009). Local Government Association.
LGA. (2019). Building cohesive communities. An LGA guide (pp. 530). Local Government Association.

Liao, C.-W., Chen, C.-H., \& Shih, S.-J. (2019). The Interactivity of video and collaboration for learning achievement, intrinsic motivation, cognitive load, and behavior patterns in a digital game-based learning environment. Computers \& Education, 133, 43-55. https://doi.org/10.1016/j.compedu.20 19.01 .013

Liimatta, T. (2015). Video as a learning tool. Creating a tutorial for Magento [Thesis]. Oulu University of Applied Sciences.

Liu, M. (2016). Blending a class video blog to optimize student learning outcomes in higher education. Internet and Higher Education, 30, 44-53. http://dx.doi.org/10.1016/j.iheduc.20 16.03 .001

Liu, Y. (2010). Social Media Tools as a Learning Resource. Journal of Educational Technology Development and Exchange, 3(1), 101-114.

Ljubojevic, M., Vaskovic, V., Stankovic, S., \& Vaskovic, J. (2014). Using Supplementary Video in Multimedia Instruction as a Teaching Tool to Increase Efficiency of Learning and Quality of Experience. The International Review of Research in Open and Distance Learning, 15(3), 273-291.

López, C. G.-G., Alonso, F. M., Morales, M. M., \& León, J. A. M. (2015). Authentic leadership, group cohesion and group identification in security and emergency teams. Psicothema, 27(1), 59-64. https://doi.org/doi: 10.7334/psicothema2014.161

López, S. D. la F., Ferrando, F., \& FabregatSanjuan, A. (2016). Learning/training video clips: an efficient tool for improving learning outcomes in Mechanical Engineering. International Journal of Educational Technology in Higher Education, 
13(6), 1-13. https://doi.org/DOI 10.1186/s41239-016-0011-4

Lu, A. (n.d.). Environment and Development (Encyclopedia of Life Support Systems). (EOLSS.

Lunenburg, F. C. (2010). Managing Change: The Role of the Change Agent. International Journal of Management, Business, and Administration, 13(1), $1-6$.

Maguire, B., \& Cartwright, S. (2008). Assessing a community's capacity to manage change: A resilience approach to social assessment (pp. 1-26). Commonwealth of Australia.

Maraña, M. (2010). Culture and Development. Evolution and Prospects (Working Papers No. 1; UNESCO Etxea, pp. 1-28). UNESCO.

Marra, R. M., Jonassen, D. H., Palmer, B., \& Luft, S. (2014). Why Problem-Based Learning Works: Theoretical Foundations. Journal on Excellence in College Teaching, 25(3\&4), 221-238.

Masats, D., Dooly, M., \& Costa, X. (2009). Exploring the potential of language learning through video making. EDULEARN09 Conferenc, Barecolna.

Mavrou, K., Douglas, G., \& Lewis, A. (2007). The use of Transana as a video analysis tool in researching computerbased collaborative learning in inclusive classrooms in Cyprus. International Journal of Research \& Method in Education, 30(2), 163-178. https://doi.org/DOI: 10.1080/17437270701383305

McKnight, J. L., \& Kretzmann, J. P. (1990). Mapping Community Capacity (pp. 113). Center for Urban Affairs and Policy Research.

Meffe, G. K., Nielsen, L. A., Knight, R. L., \& Schenborn, D. A. (2002). Ecosystem Management. Adaptive, CommunityBased Conservation. Island Press.

Mendoza, I. V. (2016). The role of cooperatives in empowering indigenous people and older persons. "Ensuring That No One Is Left
Behind: The Cooperative Sector as a Partner in the Implementation of the United Nations 2030 Agenda for Sustainable Development."

Merino, S. S., \& Carmenado, I. de los R. (2012). Capacity building in development projects. Procedia Social and Behavioral Sciences, 46, 960-967. https://doi.org/doi: 10.1016/j.sbspro.2012.05.231

Merkt, M., Weigand, S., Heier, A., \& Schwan, S. (2011). Learning with videos vs. learning with print: The role of interactive features. Learning and Instruction, 21, 687e704. https://doi.org/doi:10.1016/j.learninst ruc.2011.03.004

Moghavvemi, S., Sulaiman, A., Jaafar, N. I., \& Kasem, N. (2018). Social media as a complementary learning tool for teaching and learning: The case of youtube. The International Journal of Management Education, 16, 37-42. https://doi.org/10.1016/j.ijme.2017.1 2.001

Morley, S. (2015). What works in effective Indigenous community-managed programs and organisations (CFCA Paper No. 32; Child Family Community Australia, pp. 1-14). Australian Institute of Family Studies.

Morris, M., \& Shore, C. (2013). The Natural Environment in Development and Well-Being (Natural Environment and Climate Issues) [A World Vision Guide]. World Vision International.

Morton, B. (n.d.). An overview of international NGOs in develeopment cooperation (Possibilities for SouthSouth Cooperation?, pp. 325-352) [Case Study 7].

Mota, P., Carvalho, N., Carvalho-Dias, E., Costa, M. J., Correia-Pinto, J., \& Lima, E. (2018). Video-Based Surgical Learning: Improving Trainee Education and Preparation for Surgery. Journal of Surgical Education, 75(3), 828-835. https://doi.org/10.1016/j.jsurg.2017.0 9.027 
Müller, E., Appleton, M. R., Ricci, G., Valverde, A., \& Reynolds, D. (2015). Capacity development. In Protected Area Governance and Management, (in G. L. Worboys, M. Lockwood, A. Kothari, S. Feary and I. Pulsford (eds, pp. 251-290). ANU Press.

Nepal, S. K. (2002). Involving Indigenous Peoples in Protected Area Management: Comparative Perspectives from Nepal, Thailand, and China. Environmental Management, 30(6), $748-763$. https://doi.org/DOI: 10.1007/s00267002-2710-y

Newman, S. M. (2013). Adaptive capacity of human communities to environmental disturbance [Dissertation]. Wahington State University.

Northern Illinois University. (n.d.). ProblemBased Learning (PBL). Faculty Development and Instructional Design Center._facdev@niu.edu, www.niu.edu/facdev

Nova, J. C., Chavarro, C. I. O., \& Córdoba, A. T. Z. (2017). Educational videos: a didactic tool for strengthening English vocabulary through the development of affective learning in kids. Gist Education and Learning Research Journal, 14, 68-87.

NSW Department of Education. (n.d.). Continuity of Education: Guidelines to Support Schools using Live Video with Students. NSW. education.nsw.gov.au

OECD. (2010). Advocating for the National Strategy for the Development of Statistics Country-level Toolkit (pp. 8-88). Paris 21.

OECD. (2012). Green Growth and Developing Countries (pp. 5-65) [Consulttaion Draft].

Ohlenburg, H., Warnken, L., Zarbock, A., Güß, T., \& Lukas, R.-P. (2017). Interactive multi-perspective video-elearning tool (iMuVi) for resuscitation training in flipped classrooms. Abstracts / Resuscitation, 118S, e5e42.

http://dx.doi.org/10.1016/j.resuscitatio n.2017.08.042
Oliveira, P. B. de M. (2018). Design of Digital PID Controllers using Particle Swarm Optimization: A Video Based Teaching Experiment. IFAC PapersOnLine, 51-4, 298-303. https://doi.org/10.1016/j.ifacol.2018. 06.081

Orús, C., Barlés, M. J., Belanche, D., Casaló, L., Fraj, E., \& Gurrea, R. (2016). The effects of learner-generated videos for YouTube on learning outcomes and satisfaction. Computers \& Education, 95, 254-269. http://dx.doi.org/10.1016/j.compedu. 2016.01.007

Otto, J. M. (2010). Community development agreement model regulations \& example guidelines (Final Report No. 61482; pp. 1-81). World Bank Group.

Pacheco, F., Jao, M., Cravo, T. de A., \& Schiefer, U. (n.d.). The role of external development actors in postconflict Scenarios.

Pan American Health Organization, \& WHO. (2013). Health, Environment and Sustainable Development: Towards the Future We Want (pp. 1152). Pan American Health Organization \& WHO.

Papathomas, P., \& Goldschmidt, K. (2017). Utilizing virtual reality and immersion video technology as a focused learning tool for children with autism spectrum disorder. Journal of Pediatric Nursing, 35, 8-9. http://dx.doi.org/10.1016/j.pedn.2017 .01 .013

Pitegoff, P., Cummings, S. L., Alexander, L. T., Alvarez, A., Ball, A. S., Bennett, S. D., Crowder, P. A., Dubal, V. B., Jacob, S., Murray, K. N., Pruitt, L. R., \& Weiss, B. M. (2017). Community Development Law and Economic Justice-Why Law Matters (Research Paper Series No. 17-83; Legal Studies). Texas A\&M University.

Polman, W. (n.d.). Role of government institutions for promotion of agriculture and rural development in Asia and the Pacific Region Dimensions \& Issues (pp. 1-23) [Resource Paper]. 
Portolés, J. B. (n.d.). Culture and Development MDG-F Thematic Study: Review of Key Findings and Achievements (MDG-F Thematic Studies, pp. 4-61). MDG Achievement Fund.

Prilop, C. N., Weber, K. E., \& Kleinknecht, M. (2020). Effects of digital videobased feedback environments on preservice teachers' feedback competence. Computers in Human Behavior, 102, 120-131. https://doi.org/10.1016/j.chb.2019.08. 011

Putra, R. D. D., \& Rudito, B. (2015). Planning Community Development Program of Limbangan Traditional Market Revitalization with Social Mapping. Procedia - Social and Behavioral Sciences, 169, 143-150. https://doi.org/doi: 10.1016/j.sbspro.2015.01.296

Rajadell, M., \& Garriga-Garzón, F. (2017). Educational videos: After the why, the how. Intangible Capital, 13(5), 903923. https://doi.org/10.3926/ic.1042

Ramsay, S. A., Holyoke, L., Branen, L. J., \& Fletcher, J. (2012). Six Characteristics of Nutrition Education Videos That Support Learning and Motivation to Learn. Journal of Nutrition Education and Behavior, 44(6), 2012. http://dx.doi.org/10.1016/j.jneb.2011. 10.010

Reining, N., Kauffeld, S., \& Herrmann, C. (2019). Students' interactions: Using video data as a mean to identify competences addressed in learning factories. Procedia Manufacturing, 31, $1-7$.

https://doi.org/10.1016/j.promfg.2019. 03.001

Republic of Rwanda. (2008). Community Development policy (pp. 3-26). Ministry of Local Government.

Riach, M. (2002). Understanding Community Development (Community Development Strand, pp. 1-40) [Primary and Secondary Teacher Education Project]. Australian Agency for International Development (AusAID).

Rodríguez, L. O., Cisneros, E., Pequeño, T., Fuentes, M. T., \& Zinngrebe, Y. (2018). Building Adaptive Capacity in Changing Social-Ecological Systems: Integrating Knowledge in Communal Land-Use Planning in the Peruvian Amazon. Sustainability, 10(511), 1-28. https://doi.org/doi:10.3390/su100205 11

Ross, A. (2010). It's Time to Get SeriousWhy Legislation Is Needed to Make Sustainable Development a Reality in the UK. Sustainability, 2, 1101-1127. https://doi.org/doi:10.3390/su204110 1

Roy, R. B., \& McMahon, G. T. (2012). Video-based cases disrupt deep critical thinking in problem-based learning. Medical Education, 46, 426-435.

https://doi.org/doi:10.1111/j.13652923.2011.04197.x

Rupp, M. A., Odette, K. L., Kozachuk, J., Michaelis, J. R., Smither, J. A., \& McConnell, D. S. (2019). Investigating learning outcomes and subjective experiences in 360-degree videos. Computers \& Education, 128, 256-268.

https://doi.org/10.1016/j.compedu.20 18.09.015

Rutterford, C. (2012). Research Design. In Researching society and culture (3rd ed., pp. 118-152). SAGE Publication Ltd.

Sakmar, S. L., Wackernagel, M., Galli, A., \& Moore, D. (2011). Sustainable development and environmental challenges in the Mena region: Accounting for the environment in the 21 st century (Working Paper No. 592; pp. 1-44). The Economic Research Forum (ERF).

Salkin, P. E., \& Lavine, A. (2008). Understanding Community Benefits Agreements: Equitable Development, Social Justice and Other 
Considerations for Developers, Municipalities and Community Organizations. UCLA Journal of Environmental Law and Policy, 26(2), 291-331.

Santagata, R., \& Stürmer, K. (2014). Videoenhanced Teacher Learning: New Scenarios for Teacher Development. Open Journal per La Formazione in Rete, 2(4), 1-3. http://dx.doi.org/10.13128/formare15145

Savery, J. R. (2006). Overview of Problembased Learning: Definitions and Distinctions. The Interdisciplinary Journal of Problem-Based Learning, 1(1), 9-20.

Savin-Baden, M. (2000). Problem-based Learning in Higher Education: Untold Stories. The Society for Research into Higher Education \& Open University Press.

SCDC. (n.d.). Community Development Values. Scottish Community Development Centre.

Scheunpflug, A., \& McDonnell, I. (2008). Building Public Awareness of Development: $\quad$ Communicators, Educators and Evaluation (Policy Brief No. 35; pp. 4-37). OECD Development Centre.

Schmidt, H. G. (1983). Problem-based learning: Rationale and description. Medical Education, 17, 11-16.

Schmitz, F. M., Schnabel, K. P., Bauer, D., Woermann, U., \& Guttormsen, S. (2020). Learning how to break bad news from worked examples: Does the presentation format matter when hints are embedded? Results from randomised and blinded field trials. Patient Education and Counseling, 122.

https://doi.org/10.1016/j.pec.2020.03. 022

Scott, K. S. (2017). An Integrative Framework for Problem-Based Learning and Action Learning: Promoting Evidence-Based Design and Evaluation in Leadership Development. Human Resource Development Review, 16(1), 3-34. https://doi.org/ps://doi.org/10.1177/1 534484317693090

SDCS, CDAS, \& SCDN. (n.d.). Community Development - Everyone's Business? (pp. 1-18). Scottish Community Development Centre, Community Development Alliance Scotland, Scottish Community Development Network.

Sempere, A. M. (n.d.). The Relations between Culture and Development in the Present Context. EuroAmericano.

Shah, A. (2017). Development assistance and conditionality: Challenges in design and options for more effective assistance. EC-OECD Seminar Series on Designing better economic development policies for regions and cities, Washington DC.

Shoufan, A. (2019). Estimating the cognitive value of YouTube's educational videos: A learning analytics approach. Computers in Human Behavior, 92, 450-458.

https://doi.org/10.1016/j.chb.2018.03 .036

Shrestha, R., Shrestha, S. L., Acharya, S. G., \& Adhikari, S. (2009). Improving Community-level Governance: Adaptive Learning and Action in Community Forest User Groups in Nepal. Journal of Forest and Livelihood, 8(2), 67-77.

Silverman, D. (2010). Interpreting qualitative data. Methods for analyzing telk, text and interaction (3rd ed.). SAGE Publication Ltd.

Simonis, U. E. (1992). Poverty, environment and development. Verlag Weltarchiv, Hamburg, 27(2), 75-85. http://dx.doi.org/10.1007/BF0292617 9

Sir Wilfrid Laurier School Board. (n.d.). An Introduction to Problem-Based Learning. Educational Services.

Smit, B., \& Wandel, J. (2006). Adaptation, adaptive capacity and vulnerability. Global Environmental Change, 16, 282-292.

https://doi.org/doi:10.1016/j.gloenvc ha.2006.03.008 
Spolaôr, N., Lee, H. D., Takaki, W. S. R., Ensina, L. A., Coy, C. S. R., \& Wu, F. C. (2020). A systematic review on content-based video retrieval. Engineering Applications of Artificial Intelligence, $\quad 90(103557)$. https://doi.org/10.1016/j.engappai.202 0.103557

Steingass, S. (2015). The EU's Role in Development Cooperation: Promoting Aid Harmonisation in Times of Crisis. The EU After the Crisis: Phoenix or Albatross?, 1-21.

Stepien, W., \& Gallagher, S. (1993). Problem-based learning: As authentic as it gets. Educational Leadership, 50(7).

Stiberg, E., Holand, U., Olstad, R., \& Lorem, G. (2012). Teaching Care and Cooperation with Relatives: Video as a Learning Tool in Mental Health Work. Issues in Mental Health Nursing, 33, 528-535. https://doi.org/DOI: 10.3109/01612840.2012.687804

Sureshkumar, N. B., Anvar, Kalamony, D., \& Nair, T. S. (2015). Community Development (No. CD001; Social Work and Development, pp. 1-86). State Resource Centre.

Surgenor, D., Hollywood, L., Furey, S., Lavelle, F., McGowan, L., Spence, M., Raats, M., McCloat, A., Mooney, E., Caraher, M., \& Dean, M. (2017). The impact of video technology on learning: A cooking skills experiment. Appetite, $\quad 114, \quad 306-312$. http://dx.doi.org/10.1016/j.appet.2017 .03 .037

Syafruddin, Sumardjo, Tjitropranoto, P., \& Fatchiya, A. (2018). Community Adaptive Readiness for Ecological Changes from Agriculture to Mining in Bombana Regency. International Journal of Science and Research, 7(10), 945-950. https://doi.org/DOI: 10.21275/ART20191998

Taylor, G. S. (n.d.). What is community development (D-1449). AgriLife Communications. http://agrilifebookstore.org
Thieman, G. Y. (2008). Using Technology as a Tool for Learning and Developing 21st Century Citizenship Skills: An Examination of the NETS and Technology Use by Preservice Teachers With Their K-12 Students. Contemporary Issues in Technology and Teacher Education, 8(4), 342366.

Tortajada, C. (2016). Nongovernmental Organizations and Influence on Global Public Policy. Asia \& the Pacific Policy Studies, 3(2), 266-274. https://doi.org/doi: 10.1002/app5.134

Tripp, T. R., \& Rich, P. J. (2012). The influence of video analysis on the process of teacher change. Teaching and Teacher Education, 28, 728-739. https://doi.org/doi:10.1016/j.tate.201 2.01.011

Troseth, G. L., \& Strouse, G. A. (2017). Designing and using digital books for learning: The informative case of young children and video. International Journal of ChildComputer Interaction, 12, 3-7. http://dx.doi.org/10.1016/j.ijcci.2016. 12.002

Ubels, J., Acquaye-Baddoo, N.-A., \& Fowler, A. (2010). Capacity Development in Practice. Earthscan.

UNDP. (n.d.). Social cohesion framework. Social cohesion for stronger communities. Knowledge, Skills, Understanding (pp. 5-20). United Nations Development Programme.

UNDP. (2008). Capacity Development (pp. 1-30) [Practice Note]. United Nations Development Programme. www.capacity.undp.org

UNDP. (2009). Capacity development: A UNDP Primer (pp. 1-62). United Nations Development Programme. http://www.undp.org/capacity

UNESCO. (n.d.). The power of Culture for development (pp. 1-14). UNESCO. info.culturedevelopment@unesco.org

UNESCO. (2012). Culture: a driver and an enabler of sustainable development 
(UN System Task Team on the Post2015 UN Development Agenda, pp. 310) [Thematic Think Piece]. UNESCO.

United Nations. (2008). Achieving Sustainable Development and Promoting Development Cooperation (No. E.08.II.A.11; Dialogues at the Economic and Social Council). United Nations.

United Nations. (2013a). Access to information, participation and justice in environmental matters in Latin America and the Caribbean. Situation, outlook and examples of good practice (No. 51; Environment and Development, pp. 7-45). Economic Commission for Latin America and The Carribbean. www.eclac.org

United Nations. (2013b). Realizing the Right to Development (HR/PUB/12/4; pp. 3 535). United Nations- Human Rights office of the High commissioner.

University of Rochester. (2009). Problem Based Learning. Main Concepts. University of Rochester.

Van der Waldt, G. (2016). The Role of Government in Sustainable Development: Towards a Conceptual and Analytical Framework for Scientific Inquiry. Administratio Publica, 24(2), 49-72.

van Es, E. A. (2012). Examining the development of a teacher learning community: The case of a video club. Teaching and Teacher Education, 28, 182-192.

https://doi.org/doi:10.1016/j.tate.2011 .09 .005

Van Gorkum, E. (2015). How to effectively strengthen advocacy capacity. Lessons learnt from the DCR Programme 20112015. (pp. 6-36). DCR Advocacy.

Vollmer, F. (2012). Increasing the visibility and effectiveness of development cooperation. How to reconcile two competing objectives? In Studies / Deutsches Institut für Entwicklungspolitik (pp. 1-86). Deutsches Institut für Entwicklungspolitik gGmbH.
Vural, Ö. F. (2013). The Impact of a Question-Embedded Video-based Learning Tool on E-learning. Educational Sciences: Theory \& Practice, 13(2), 1315-1323.

Wang, J., \& Antonenko, P. D. (2017). Instructor presence in instructional video: Effects on visual attention, recall, and perceived learning. Computers in Human Behavior, 71, 79-89.

http://dx.doi.org/10.1016/j.chb.2017. 01.049

Wang, P. Z. T., Xie, W. Y., Nair, S., Dave, S., Shatzer, J., \& Chahine, S. (2020). A Comparison of Guided Video Reflection versus Self-Regulated Learning to Teach Knot Tying to Medical Students: A Pilot Randomized Controlled Trial. Journal of Surgical Education. https://doi.org/10.1016/j.jsurg.2020.0 2.014

Warrick, O. (2012). The adaptive capacity of the Tegua island community, Torres Islands, Vanuatu (pp. 1-70). Commonwealth of Australia.

Watson, B., Brundtland, G. H., Ehrlich, P., Goldemberg, J., Hansen, J., Lovins, A., Likens, G., Manabe, S., May, B., Mooney, H., Robert, K.-H., Salim, E., Sato, G., Solomon, S., Stern, N., \& Swaminathan, M. (2014). Environment and Development Challenges: The Imperative to Act. the Asahi Glass Foundation Blue Plant Laureates for Rio+20.

Wendel, M. L., Burdine, J. N., McLeroy, K. R., Alaniz, A., Norton, B., \& Felix, M. R. J. (2009). Community capacity: Theory and application. https://www.researchgate.net/publica tion/283466286

Wider. (1991). The Environment and Emerging Development Issues (No. 7; Study Group Series, pp. 1-20). World Institute for Development Economics Research.

WIPO. (2016). Customary Law and Traditional Knowledge. World Intellectual Property Organization. 
Witsil, A. J. C., \& Johnson, J. B. (n.d.). Volcano video data characterized and classified using computer vision and machine learning algorithms. Geoscience Frontiers. https://doi.org/10.1016/j.gsf.2020.01.0 16

Woolfitt, Z. (2015). The effective use of video in higher education (pp. 1-49). Inholland University of Applied Sciences.

Yew, E. H. J., \& Goh, K. (2016). ProblemBased Learning: An Overview of its Process and Impact on Learning. Health Professions Education, 2, 7579. http://dx.doi.org/10.1016/j.hpe.2016. 01.004

Yip, J., Wong, S.-H., Yick, K.-L., Chan, K., \& Wong, K.-H. (2019). Improving quality of teaching and learning in classes by using augmented reality video. Computers \& Education, 128, 88-101.

https://doi.org/10.1016/j.compedu.20 18.09.014

Yousef, A. M. F., Chatti, M. A., \& Schroeder, U. (2014). The State of Video-Based Learning: A Review and Future Perspectives. International Journal on Advances in Life Sciences, $6(3 \& 4), 122-135$. 